\title{
STRATEGI PENYADARAN BERZAKAT KELAS MENENGAH MUSLIM: STUDI PADA LAZIS MUHAMMADIYAH SURABAYA
}

\author{
Wahanani Mawasti \\ STID Al-Hadid, Surabaya \\ wahananimawasti@yahoo.co.id
}

\begin{abstract}
Abstrak: Potensi dana zakat, infak, dan sadaqah di Indonesia sangat besar, hal tersebut didorong oleh pertumbuhan jumlah masyarakat muslim kelas menengah di Indonesia. Meskipun potensi dana zakat di Indonesia sangat besar, tetapi masih terdapat beberapa masalah berzakat, yaitu terkait rendahnya kesadaran berzakat. Maka LAZIS Muhammadiyah Surabaya, sebagai salah satu lembaga amil zakat berperan dalam mengedukasi dan mengelola zakat di Indonesia agar lebih optimal. LAZIS Muhammadiyah Surabaya melaksanakan berbagai strategi penyadaran berzakat kepada masyarakat muslim kelas menengah di kota Surabaya melalui berbagai jenis media komunikasi secara terencana. Studi ini menjelaskan proses LAZIZ Muhammadiyah Surabaya dalam merumuskan strategi penyadaran berzakat dan menumbuhkan kepercayaan masyarakat muslim menengah di kota Surabaya pada tahun 2016. Menggunakan teori perencanaan dakwah, melalui pendekatan kualitatif deskriptif dengan wawancara mendalam dan dokumentasi. Kesimpulan yang diperoleh bahwa LAZIS Muhammadiyah menggunakan berbagai jenis strategi penyadaran berzakat antara lain melalui : media sosial, sosialisasi zakat, program event, hubungan masyarakat, majalah, brosur dan lain sebagainya. LAZIS Muhammadiyah Surabaya menyusun strategi penyadaran berzakat dengan menerapkan langkah-langkah perencanaan dakwah secara sistematis dengan mempertimbangkan ciri khas karakter masyarakat kelas menengah sebagai sasaran (mitra) dakwah yang dituju dan kondisi lingkungan internal maupun eksternal dakwah yang selainnya.

Kata kunci: penyadaran berzakat, perencanaan dakwah, kelas menengah muslim, LAZIS Muhammadiyah Surabaya
\end{abstract}

\begin{abstract}
Potency of funds of zakah, infaq and sadaqah in Indonesia is tremendously big. It is encouraged by the growth of middle class moslems in Indonesia. Despite the fact that the potency of zakah fund in Indonesia is big, some problems on zakah remains appear. It is related to the low zakah-consciousness. Therefore, LAZIS Muhammadiyah Surabaya, as one of zakah-collecting-institutions, plays a part on educating and organizing zakah in indonesia in order to be more optimal. LAZIS Muhammadiyah Surabaya conducts various strategies of promoting zakah-consicousness to middle class moslem community in Surabaya through a variety of communication media in a planned way. This study aims to describe the process of LAZIS Muhammadiyah Surabaya on formulating strategies to promote zakah-consciousness and cultivating social trust to middle class moslems in Surabaya in 2016. This study uses the theory of da'wah planning, through qualitative descriptive approach by using in-depth interview and documenting. It concludes that LAZIS Muhammadiyah Surabaya has applied various kinds of strategies for promoting zakah-consciousness through: social media, socializing zakah, event program, social relationship, magazine, brochure, and so forth. LAZIS Muhammadiyah Surabaya arranges strategies of promoting zakah-consciousness by applying steps of da'wah planning systematically. These steps of da'wah planning consider typical characteristics of middle class society as target / partner of da'wah concerned and other internal and external environmental conditions of da'wah.
\end{abstract}


Key words: zakah-consciousness, da'wah planning, middle class moslem, LAZIS Muhammadiyah Surabaya

\section{Pendahuluan}

Zakat adalah salah satu rukun Islam yang sekaligus instrumen untuk meningkatkan perekonomian umat Islam. Di negara Indonesia yang mayoritas penduduknya adalah muslim, potensi dana zakat, infak dan sedekah sangatlah besar. Indonesia adalah negara muslim terbesar di dunia dengan peningkatan jumlah kelas menengah muslim yang pesat dan tinggi. Haedar Nasir (Ketua Umum Pengurus Pusat [PP] Muhammadiyah) menyampaikan bahwa potensi jumlah masyarakat muslim kelas menengah di Indonesia sekitar 171 juta orang. ${ }^{1}$ Badan Amil Zakat Nasional (Baznas) memperkirakan potensi zakat dari kelas menengah muslim Indonesia dapat mencapai 200 trilyun. ${ }^{2}$ Menurut Ketua umum Baznas Didin Hafidhuddin saat ini masih $15 \%$ saja dari potensi dana zakat dari masyarakat Indonesia yang telah terkumpulkan. ${ }^{3}$

Beberapa penelitian terdahulu pernah dilakukan terkait masalah adanya gap yang sangat besar antara potensi dana zakat yang ada di Indonesia dan realisasinya. Beberapa penelitian tersebut menunjukan bahwa salah satu masalah zakat dikarenakan rendahnya kesadaran masyarakat terhadap berzakat. Misalnya:

1 LAZIS Muhammadiyah Kota Surabaya, Majalah Donatur LAZIS Muhammadiyah, Edisi 101 Tahun IX, Sya'ban 1437, Mei 2016, 10.

2 Suryanto, "Ketum Baznas: potensi zakat Indonesia Rp 200 triliun", dalam http: // www.antaranews.com/ berita/ 509484/ ketumbaznas-potensi-zakat-indonesia-rp200-triliun, 1 Maret 2016.

${ }^{3}$ Ibid
Hasil penelitian sebelumnya yang dilakukan oleh Indrijatiningrum menyatakan bahwa persoalan gap potensi dana zakat dan realisasinya salah satunya disebabkan oleh adanya masalah terkait kesadaran berzakat, selain juga ada faktor-faktor lain yang dipandang berpengaruh seperti masalah kelembagaan pengelolaan zakat dan manajemen zakat yang belum terpadu. ${ }^{4}$

Selain itu, Chalikuzhi dalam disertasinya menyatakan beberapa masalah-masalah utama yang penting terkait pengelolaan zakat: (1) rendahnya pengetahuan atau kesadaran berzakat yang berakibat tidak ketidakefektifan pengumpulan zakat, hal ini berimplikasi perlunya sosialisasi zakat guna meningkatkan kesadaran membayar zakat; (2) rendahnya keimanan juga memengaruhi ketidakefektifan pengumpulan zakat; (3) perbedaan pengetahuan atau pandangan terhadap fikih zakat juga merupakan faktor penghambat ketidakoptimalan penghimpunan zakat. ${ }^{5}$ Studi lain dilakukan oleh Saneb Ahmad dkk., Ahmad menyatakan bahwa potensi masalah zakat yang ada di Indonesia adalah masih rendahnya pemahaman dan kesadaran umat Islam tentang kewajiban membayar zakat dan masalah berikutnya adalah rendahnya kesadaran masyarakat untuk

4 Nurul Huda dkk, "Prioritas Solusi Permasalahan Pengelolaan Zakat Dengan Metode AHP (Studi Di Banten dan Kalimantan Selatan)," Jurnal Al-lqtishad, Vol. VI No. 2, (Juli 2014), 225.

5 Ibid. 
menyalurkan zakat pada lembaga pengelola zakat. ${ }^{6}$

Potensi dana zakat di Indonesia yang belum terhimpun secara maksimal dikarenakan rendahnya kesadaran berzakat. Kesadaran berzakat masyarakat yang rendah disebabkan oleh faktor kurangnya kegiatan sosialisasi berzakat yang berimplikasi pada pemahaman maupun kesadaran masyarakat Indonesia yang rendah. ${ }^{7}$ Ketua PP Lembaga Amil Zakat Infak Sedekah Nahdlatul Ulama (LAZISNU) KH. Masyhuri Malik, menyatakan bahwa meski mayoritas penduduk indonesia beragama Islam, kesadaran menunaikan rukun islam yang ketiga itu ternyata masih rendah. Sampai saat ini, pengumpulan (fundraising) zakat dari seluruh lembaga amil zakat yang ada di Indonesia hanya mencapai sekitar Rp1,5 triliun. Itu berarti baru 1,5\% dari potensi zakat yang sesungguhnya. Karena itu sosialisasi kesadaran berzakat, manfaat zakat dan manajemen pengelolaan zakat ini harus terus ditingkatkan terhadap mereka yang wajib mengeluarkan zakat (muzaki), mereka yang berhak menerima zakat (mustahiq) maupun pengelola zakat (amil) itu sendiri. ${ }^{8}$

Masalah kesadaran berzakat bukan hanya terjadi di Indonesia, namun juga mungkin terjadi pada masyarakat Surabaya.

\footnotetext{
${ }^{6}$ Rusti Rahayu, "Faktor-Faktor Determinan Motivasi Muzaki Membayar Zakat Ke Lembaga Zakat," (Thesis, UIN Sunan Kalijaga, Yogyakarta, 2015), 4.

${ }^{7}$ Tim Redaksi LAZIS NU, "Training Manajemen Zakat LAZISNU: Revitalisasi Peran LAZ dalam Pengentasan Kemiskinan," LAZISnu.or.id. dalam http://www.LAZISnu.or.id/berita/print/100/10 0, 1 Maret 2016.

8 Ibid.
}

Berdasarkan wawancara dengan salah satu narasumber (Pengurus Lembaga Amil Zakat Infak Sedekah [LAZIS] Muhammadiyah Surabaya) menyampaikan bahwa masih banyak ditemui muzaki yang belum memahami berbagai kewajiban berzakat. Selama ini masyarakat hanya memahami zakat hanya dalam bentuk zakat fitrah, sedangkan pemahaman pada berzakat mal (zakat emas, perak, perniagaan, penghasilan dan lain sebagainya) masih sangat sedikit. Kurangnya kesadaran tentang zakat mal, misalnya ditunjukan dari minimnya pengetahuan tentang dalildalil kewajiban menunaikan zakat mal, apa saja harta benda yang harus dizakati, jumlah yang harus dikeluarkan atau pun pemahaman tentang waktu mengeluarkannya. Narasumber tersebut juga menuturkan bahwa masyarakat belum sepenuhnya terinternalisasi bahwa zakat itu sebenarnya merupakan sebuah kewajiban yang sama dengan salat, keduanya merupakan rukun Islam. Banyak masyarakat yang lebih senang membayar infak karena besarannya sukarela dibandingkan menunaikan zakat. ${ }^{9}$ Selain itu, masih banyak masyarakat yang tidak memahami bahwa zakat memiliki banyak kemanfaatan baik bagi diri sendiri maupun masyarakat secara langsung.

"Yah saya kira untuk melihat kesadaran berzakat, dapat dilihat dari ini aja ya, dilihat dari kita pertemuan foz, apa forum zakat itu, forum lembaga zakat itu kan mesti ngumpul dari berbagai lembaga amil zakat di Surabaya. Dari forum itu kira-kira masih 30\% lah zakat itu, yah masih kecil dan masih banyak yang belum sadar. Tapi kalau berinfak, bershodaqoh itu lebih

\footnotetext{
${ }^{9}$ Aditio, (Kordinator Media Sosial dan Majalah LAZIS MUHAMMADIYAH Surabaya), Wawancara, Wisata Kuliner Mulyorejo Surabaya, 1 Juni 2016, pukul 19.00-21.00.
} 
mudah. soalnya zakat itu kan harus menghitung, hartanya dihitung, asetnya dihitung, kadang kan males dan tidak memahami zakat orang itu, seperti pajak. Kalau infak kan bebas, kita mau tertarik infak untuk anak yatim, disabilitas, fisabilillah, yah kita tinggal ini aja memberikan sesukanya. Yah kita kumpul dengan teman-teman yang lain ya sama juga zakatnya itu masih relative yah 30\% nan lah dari total." 10

Salah satu Lembaga Amil Zakat (LAZ) yang eksis dalam mengedukasi zakat masyarakat di Surabaya adalah LAZIS Muhammadiyah Surabaya. LAZIS Muhammadiyah berharap dengan meningkatnya kesadaran masyarakat dalam berzakat sekaligus dapat meningkatkan dana zakat yang dapat terhimpun di lembaga amil zakat. Usaha penyadaran berzakat yang dilakukan LAZIS Muhammadiyah Surabaya merupakan bentuk amanat pelaksanaan UndangUndang Nomor 23 Tahun 2011 tentang Pengelolaan Zakat. ${ }^{11}$ Undang-undang tersebut menjelaskan fungsi LAZ salah satunya adalah membantu mengumpulkan zakat dengan baik, sehingga dapat meningkatkan daya guna dari zakat. Untuk dapat meningkatkan pengumpulan zakat dengan optimal, dibutuhkan fungsi LAZ sebagai lembaga yang mengedukasi atau melaksanakan penyadaran berzakat pada masyarakat.

LAZIS Muhammadiyah Surabaya sebagai LAZIS nasional dan profesional, memiliki komitmen dalam meningkatkan kesadaran berzakat masyarakat, khususnya pada masyarakat muslim kelas menengah di kota Surabaya. Berdasarkan artikel yang

\footnotetext{
${ }^{10}$ Aditio, Wawancara oleh Penulis, Surabaya, 1 Juni 2016.

${ }^{11}$ Undang-Undang Republik Indonesia Nomor 23 Tahun 2011, Pasal 17.
}

ditulis di Majalah LAZIS Muhammadiyah Surabaya edisi 101 tahun IX, menunjukkan bahwa masyarakat kelas menengah muslim di Indonesia memiliki potensi yang sangat besar untuk berzakat. Namun, di sisi lain masyarakat kelas menengah muslim memiliki karakter yang semakin cerdas dalam hal kesadaran beragama. Hal tersebut termasuk perilaku beragama dalam membayar zakat. ${ }^{12}$ Masyarakat kelas menengah muslim, tidak mau begitu saja memberikan dana sosial mereka jika tidak memahami dengan baik kewajiban membayar zakat serta nilai kemanfaatan berzakat. Apalagi jika harus menyalurkan kepada lembaga yang tidak memiliki visi, tidak disiplin pencatatan keuangannya, tidak akurat distribusi (penyaluran) zakatnya, dan tidak transparan laporan keuangannya. Oleh karena itu, untuk menyadarkan berzakat dibutuhkan usaha yang secara konsisten dilakukan oleh LAZIS Muhammadiyah.

Dalam rangka mewujudkan komitmen meningkatkan kesadaran berzakat, khususnya di kalangan masyarakat muslim kelas menengah, LAZIS Muhammadiyah Surabaya memiliki serangkaian upaya penyadaran berzakat melalui berbagai media komunikasi. Pada tahun 2016, LAZIS Muhammadiyah melaksanakan penyadaran berzakat dan penumbuhan kepercayaan melalui: event, brosur, majalah, sosialisasi zakat, kerjasama dengan berbagai lembaga, maupun media sosial. Usaha penyadaran berzakat yang dilaksanakan oleh LAZIS Muhammadiyah terus mengalami perkembangan, jika pada

12 LAZIS Muhammadiyah Kota Surabaya, Majalah Donatur LAZIS Muhammadiyah, Edisi 101, Tahun IX, Sya'ban 1437, (Surabaya: LAZIS Muhammadiyah Surabaya, Mei 2016), 13. 
masa awal berdirinya (tahun 2008) lembaga ini hanya menggunakan media majalah, iklan di koran dan getok tular dalam menyadarkan masyarakat berzakat, namun pada tahun 2016 usaha penyadaran berzakat semakin dikembangkan dalam berbagai cara yang dipandang lebih sesuai dengan kondisi.

LAZIS Muhammadiyah Surabaya tidak langsung menyasar semua kalangan dalam melakukan penyadaran berzakat. Pada tahun 2016, lembaga ini lebih memfokuskan pada penyadaran berzakat anggota Muhammadiyah yang kebanyakan tergolong masyarakat kelas menengah muslim. Hal itu berdasarkan pertimbangan bahwa LAZIS Muhammadiyah Surabaya memiliki potensi yang sangat besar dalam memobilasi masyarakat muslim kelas menengah untuk berzakat, sebab sebagian besar anggota Muhammadiyah tergolong masyarakat muslim kelas menengah yang tinggal di perkotaan. Organisasi Muhammadiyah memiliki kekuatan jaringan yang luas untuk memobilisasi kelas menengah muslim agar mampu menyalurkan zakat, infak, dan sedekah untuk para duafa melalui LAZIS Muhammadiyah..$^{13}$ Potensi dana zakat dari masyarakat muslim kelas menengah yang dapat dimobilisasi oleh LAZIS Muhammadiyah sebesar Rp 525 miliar. ${ }^{14}$ Jumlah tersebut diproyeksikan dari dua persen jumlah warga Muhammadiyah yang mau mengeluarkan zakat, infak dan

${ }^{13}$ Ibid, 10.

14 Republika, "LAZIS Muhammadiyah Filantropi Tulang Punggung Gerakan Islam," Republika.co.id,

http://khazanah.republika.co.id/berita/duniaislam/wakaf/15/08/07/nspv8r313-LAZIS Muhammadiyah-filantropi-tulang-punggunggerakan-islam diakses, 07 januari 2016. sedekah. Warga Muhammadiyah yang sudah memiliki Kartu Tanda Anggota atau Nomor Baku Muhammadiyah (KTA dan NBM) mencapai 1,5 juta orang. Angka potensi dana zakat itu didapatkan dari perhitungan rata-rata sumbangan $\mathrm{Rp}$ 30.000 tiap orang anggota Muhammadiyah. ${ }^{15}$

Strategi penyadaran berzakat adalah serangkaian usaha yang dilakukan oleh LAZIS Muhammadiyah Surabaya untuk memberikan kesadaran masyarakat agar tergerak untuk menunaikan kewajiban zakatnya. Dalam konteks penelitian ini masyarakat yang menjadi sasaran adalah masyarakat muslim kelas menengah kota Surabaya. Masyarakat muslim kelas menengah yang dimaksud di sini adalah calon donatur Lembaga Amil Zakat Muhammadiyah Surabaya yang memiliki tingkat ekononomi kelas menengah. Kelas ekonomi menengah menurut Bank Indonesia dan Credit Suisse memiliki ratarata pendapatan antara lain 5-6 juta rupiah. $^{16}$

Terdapat beberapa komponen dalam usaha penyadaran berzakat, antara lain: (1) adanya subjek (komunikator) yang melakukan aktivitas penyadaran berzakat, (2) adanya objek sasaran penyadaran berzakat, (3) adanya tujuan dari aktivitas dakwah yang dilakukan, (4) adanya pesanpesan penyadaran, (5) media yang digunakan untuk menyadarkan berzakat. Jika merujuk pada komponen-komponen yang ada dalam kegiatan penyadaran

\footnotetext{
${ }^{15}$ Ibid.

${ }^{16}$ Ayu Agustin, "Konstruksi dan Representasi Gaya Hidup Muslim Perkotaan: Studi Kasus Hijabers Community di Jakarta," (Skripsi, Universitas Indonesia, Jakarta, 2012), 1.
} 
berzakat, pada dasarnya aktivitas penyadaran berzakat juga merupakan bentuk dari aktivitas dakwah. Pengertian dakwah sendiri adalah kegiatan menyeru pada nilai-nilai Islam yang mana ajarannya terdapat dalam Alquran dan Hadis. ${ }^{17}$ Oleh karena itu, dalam meneliti strategi penyadaran berzakat LAZIS Muhammadiyah Surabaya, digunakan perspektif dakwah yaitu perencanaan strategi dakwah. Berdasarkan uraian di atas, tulisan ini memaparkan proses LAZIS Muhammadiyah Surabaya dalam merumuskan strategi penyadaran berzakat untuk meningkatkan kesadaran berzakat masyarakat muslim kelas menengah. Studi terdahulu terkait Lembaga Amil Zakat Muhammadiyah pernah dilakukan oleh Dewi Laela Hilyanti ${ }^{18}$ dan Budi Arsanti. ${ }^{19}$ Namun, selama ini penelitian masih banyak memfokuskan pada masalah pengelolaan dan distribusi zakat sedangkan tulisan ini lebih menekankan pada strategi penyadaran berzakat yang dilakukan Lembaga Amil Zakat Muhammadiyah Surabaya untuk masyarakat muslim kelas menengah.

Studi terdahulu dengan tema masyarakat kelas menengah hanya ditemukan dalam dua penelitian yaitu dilakukan oleh Nuki

\footnotetext{
${ }^{17}$ Kustadi Suhandang, IImu Dakwah Perspektif Komunikasi, (Bandung: Remaja Rosdakarya, 2013), 19.

${ }^{18}$ Dewi Laela Hilyanti, “Aplikasi Manajemen Distribusi Zakat Untuk Usaha Produktif (Studi Kasus Pada LAZIS Muhammadiyah Ranting Tanjung, Kecamatan Purwokerto Selatan, Kabupaten Banyumas," (Skripsi, Universitas Islam Negeri Malang, Malang, 2007).

${ }^{19}$ Budi Arsanti, "Pengelolaan Zakat Pada LAZIS Mumahhamadiyah Kabupaten Gunung Kidul," (Skripsi, Universitas Islam Negeri Kalijaga, Yogyakarta, 2007).
}

Mayasari, 20 yang mana lebih melihat perilaku kelas muslim menengah dalam melaksanakan umrah secara berkala. Studi lain ditulis oleh A. Ranggabumi Nuswantoro, ${ }^{21}$ studi tersebut melihat kelas menengah dalam melakukan pertukaran informasi di tengah masa pemilu. Dari dua studi di atas yang membahas tentang kelas menengah, setidaknya memberikan gambaran tentang bagaimana karakteristik masyarakat kelas menengah secara sosiologis. Namun, studi-studi di atas tidak memfokuskan pada strategi penyadaran berzakat untuk membentuk kesadaran berzakat kelas menengah.

\section{Perencanaan Dakwah Penyadaran Berzakat}

\section{Pengertian Perencanaan}

Perencanaan merupakan proses menetapkan sasaran-sasaran yang ingin dicapai, menentukan tindakan-tindakan yang harus dilakukan, merancang jabatan organisasi yang ditujukan untuk menjalankan cara/tindakan-tindakan yang akan dilakukan, serta menetapkan pejabat yang harus bertanggung jawab terhadap tindakan-tindakan yang diperlukan untuk mencapai sasaran/tujuan. ${ }^{22}$ Perencanaan dibuat dengan sadar, didasarkan pada

\footnotetext{
${ }^{20}$ Nuki Mayasari, "Rechaging Faith : The Practice of Mutltiple Umrah Trips Among Middle Class in Yogyakarta," (Thesis, Universitas Gajah Mada, Yogyakarta, 2014).

21 A. Ranggabumi Nuswantoro, "Kelas Menengah \& Kondisi Deliberatif : Pertukaran Informasi Kompasianer Pada Masa Kampanye Pilkada DKI Jakarta 2012 dan Pemenuhannya Terhadap Kondisi Deliberatif", (Tesis, Universitas Gajah Mada, Yogyakarta, 2014).

${ }^{22}$ Harold Koontz, Cyril O' Donnel dan Heinz Weihrich, Manajemen Jilid 1 (Edisi kedelapan), (Erlangga, 1994), 120.
} 
tujuan, pengetahuan, kalkulasi pada kondisi-kondisi yang diramalkan di masa mendatang. ${ }^{23}$ Sedangkan menurut Stephen $P$ Robins dan Mary Coulter perencanaan adalah proses mendefinisikan sasaran organisasi, menetapkan strategi menyeluruh mencapai sasaran, menyusun serangkaian cara yang menyeluruh untuk mengintegrasikan dan mengorganisasi pekerjaan organisasi. Perencanaan menyangkut hasil (apa yang harus dikerjakan) dan sarana (bagaimana cara melakukannya). ${ }^{24}$

\section{Prosedur (Tahap) Perencanaan}

Secara sederhana, Hani Handoko mengembangkan langkah perencanaan dalam empat tahap yaitu: (a) menetapkan tujuan atau serangkaian tujuan yaitu: tujuan yang berangkat dari keinginankeinginan yang ingin dicapai organisasi, kebutuhan organisasi atau kelompok tertentu, ${ }^{25}$ (b) merumuskan keadaan saat ini, yaitu : mengetahui informasi-informasi terkait sumber daya yang tersedia untuk mencapai tujuan, posisi (kondisi) organisasi saat ini dan memahami kondisi yang akan datang, (c) mengidentifikasi segala kemudahan, hambatan, peluang dan ancaman, (d) mengembangkan serangkaian rencana atau kegiatan untuk mencapai tujuan. Pada tahap ini meliputi: mengembangkan alternatif cara (strategi) yang memungkinkan untuk mencapai tujuan dan memilih (membandingkan) berbagai alternatif terbaik yang ada dengan kondisi yang dihadapi organisasi. ${ }^{26}$

\footnotetext{
23 Ibid.

24 Stephen P. Robbins \& Mary Coulter, Manajemen edisi kedelapan Jilid 1, (Jakarta: Indeks, 2009), 192.

${ }^{25}$ T. Hani Handoko, Manajemen Edisi 2,, (Yogyakarta : BPFE-Yogyakarta, 1994), 79.

${ }^{26}$ Ibid.
}

\section{Pengertian Dakwah}

Menurut Abdul Basit, dakwah berasal dari bahasa arab yaitu دعا - يدعو - دعوة yang berarti memanggil, mengundang, mengajak kepada sesuatu; mengubah dengan perkataan, perbuatan, dan amal. ${ }^{27}$ Istilah-istilah lain yang diberi sama dengan dakwah adalah tablig, amar makruf dan nahi mungkar, mau'izdzhoh, hasanah, tabsyir, indszhar, washiyah, tarbiyah, taklim dan khotbah. ${ }^{28}$ Dakwah adalah sebuah proses yang aktif, persuasif, dan komprehensif. Dakwah haruslah mencari orang sebagai mitra dakwah, lalu memberikan persuasi dan mengajak ke jalan Allah. Kesempurnaan dakwah adalah ketika mitra dakwah menjadi pendakwah. ${ }^{29}$ Dakwah menurut Prof. Dr. Ahmad Mubarok secara umum didefinisikan sebagai pekerjaan mengomunikasikan pesan Islam manusia, secara operasional dakwah adalah aktivitas mengajak, mendorong manusia kepada tujuan yang dapat diambil dari Alquran dan hadis untuk diterapkan dalam kehidupan manusia. Tujuan dakwah berdasarkan ruang lingkupnya bisa diperluas dan dipersempit. ${ }^{30}$ Berdasarkan beberapa pengertian di atas, penulis dapat menyimpulkan bahwa: a) Dakwah adalah penyampaian pengetahuan Islam kepada orang lain dengan cara yang bersifat persuasif; b) Dakwah adalah memberikan

\footnotetext{
${ }^{27}$ Abdul Basit, Filsafat Dakwah, (Jakarta: PT RajaGrafindo Persada, 2013), 43.

${ }^{28}$ M. Munir dan Wahyu llaihi, Manajemen Dakwah edisi Pertama, (Jakarta: Kencana Prenada Media Group, 2009), 17.

${ }^{29}$ Moh. Ali Azis, Ilmu Dakwah (Edisi Revisi), (Jakarta : Prenadamedia Group, 2016), 41.

${ }^{30}$ Faizah dan Lalu Muchsin Effensi, Psikologi Dakwah, (Jakarta: Kencana Prenada Media Group, 2009), xiii-xiv.
} 
kesadaran terhadap nilai-nilai amar makruf (ajaran kepada kebaikan) dan nahi mungkar (mencegah kemunkaran); c) dakwah memiliki tujuan yaitu terbentuknya individu atau masyarakat yang taat dan mengamalkan ajaran Islam dalam berbagai aspek kehidupan.

\section{Unsur Dakwah}

Dakwah memiliki beberapa unsur antara lain: (a) dai (subjek yang berdakwah), yaitu orang yang melakukan aktivitas dakwah. Dalam ilmu komunikasi dakwah, pendakwah merupakan komunikator atau orang yang menyampaikan pesan. Pendakwah bisa individu maupun lembaga, (b) mad'uw (mitra dakwah) yaitu sebagai penerima/sasaran dakwah, (c) maddah (Materi Dakwah): pesan dakwah adalah apa yang disampaikan dalam proses kegiatan dakwah. Pesan dakwah berkaitan dengan bahasa atau simbol yang digunakan, makna yang di persepsi atau diterima oleh seseorang, dan penerimaan pesan dakwah yang bersumber dari Alquran, hadis maupun pesan penunjang lainnya selain dari Alquran dan hadis, (d) wasilah (media dakwah) adalah alat yang menjadi perantara penyampaian pesan dakwah kepada mitra dakwah ${ }^{31}$ (e) thariqah (metode dakwah secara bahasa memiliki arti pendekatan dalam dakwah (teknik atau disebut pula taktik dakwah). ${ }^{32}$ Metode dakwah dapat bermacam-macam bentuknya, seperti: melalui dialog, nasehat/ceramah, konseling, metode karya tulis (tulisan, gambar dan surat), pemberdayaan masyarakat, metode kelembagaan dan lain sebagainya yang

\footnotetext{
${ }^{31}$ Moh. Ali Azis, Ilmu Dakwah (Edisi Revisi), (Jakarta : Prenadamedia Group, 2016), 403.

32 Ibid, 345
}

bersifat bil hikmah, ${ }^{33}$ (f) atsar (efek dakwah) yaitu efek dari kegiatan dakwah meliputi tiga hal yaitu: pada sisi kognitif, afeksi dan behavioral. ${ }^{34}$

\section{Perencanaan Dakwah}

Dari serangkaian pandangan tentang perencanaan dan dakwah, dapat disimpulkan bahwa perencanaan dakwah adalah langkah-langkah membuat keputusan berupa tujuan dakwah dan cara (strategi) dakwah yang hendak dilakukan untuk mencapai tujuan dengan mempertimbangkan kondisi internal maupun eksternal. Tujuan dakwah bisa berupa efek (atsar) yang diharapkan dari aktivitas dakwah yang dilaksanakan, seperti perubahan pemikiran (kognisi), perasaan maupun perilaku pada mitra dakwah. Sedangkan, di dalam cara (strategi) dakwah terdapat komponen, antara lain: subjek dakwah $\left(d a^{\prime} i\right)$, materi dakwah (maddah), media dakwah (wasilah), dan metode dakwah (thariqah) yang akan digunakan untuk mencapai tujuan dakwah.

Langkah-langkah dalam perencanaan dakwah meliputi: (a) merumuskan tujuan dakwah (efek dakwah yang diharapkan dan mitra dakwah yang disasar); (b) mengidentifikasi kondisi terkait baik aspek internal maupun eksternal yang dipandang memengaruhi pencapaian dakwah. Dari pemetaan kondisi tersebut, lembaga dakwah kemudian melakukan analisis dan mengenali kondisi-kondisi yang dipandang akan menjadi kelemahan, kelebihan, peluang dan ancaman di masa mendatang; (c) merencanakan strategi dakwah yang akan dilaksanakan, meliputi: subjek

\footnotetext{
33 Ibid.

34 Ibid, 456.
} 
dakwah (dai), materi dakwah (maddah), media dakwah (wasilah), dan metode dakwah (thariqah) yang akan digunakan untuk mencapai tujuan dakwah maupun merumuskan cara penunjang operasionalisasi cara utama lainnya.

\section{Metodologi}

Metode yang digunakan dalam menggali data adalah kualitatif, studi lapangan dan deskripsi. Metode kualitatif merupakan serangkaian kegiatan menyaring informasi dari suatu objek, dihubungkan dengan pemecahan suatu masalah baik dari sudut pandang praktis atau teoritis. Informasi yang diperoleh tersebut akan dipelajari dan ditafsirkan dengan usaha memahami maknanya sesuai dengan sudut pandang sumber data. ${ }^{35}$ Periset dalam penelitian kualitatif adalah bagian integral dari data yang secara aktif menjadi instrumen untuk terjun ke lapangan secara mendalam. ${ }^{36}$ Secara umum studi ini adalah penelitian kualitatif, hal itu dapat dilihat dari langkah pengumpulan datanya adalah penelitian kualitatif. Penulis menggunakan studi awalan terlebih dahulu dengan menggunakan metode wawancara dan penelusuran website, kemudian melanjutkan perolehan data lebih mendalam dengan metode wawancara mendalam. Metode penggalian data menggunakan wawacara semi terstruktur dan informan yang ditetapkan secara purposive. Informan dalam studi ini dijelaskan pada tabel 1.

\footnotetext{
${ }^{35}$ Hadri Nawawi dan M. Matini Nawawi, Instrumen Penelitian Bidang Sosial, (Yogyakata: Gajah Mada University Press,1992), 209.

${ }^{36}$ Rachmat Krisyantono, Teknik Praktis Riset Komunikasi: Disertai Contoh Praktis Riset Media, Public Relation, Advertising, Komunikasi Organisasi, Komunikasi Pemasaran, (Jakarta: Kencana, 2010), 57.
}

Analisis data dalam penelitian ini melalui beberapa tahap antara lain: Pertama, analisis data sebelum penelitian yaitu melakukan studi pendahuluan dan melalui data sekunder untuk menentukan fokus penelitian. Kedua, analisis data di lapangan dengan metode Miles dan Huberman yaitu melalui reduksi data, penyajian data dan terakhir adalah verifikasi (trianggulasi data sumber), analisis dan penarikan kesimpulan. ${ }^{37}$

\section{Tabel 1}

Identitas Informan (Pengurus LAZIS

Muhammadiyah Surabaya)

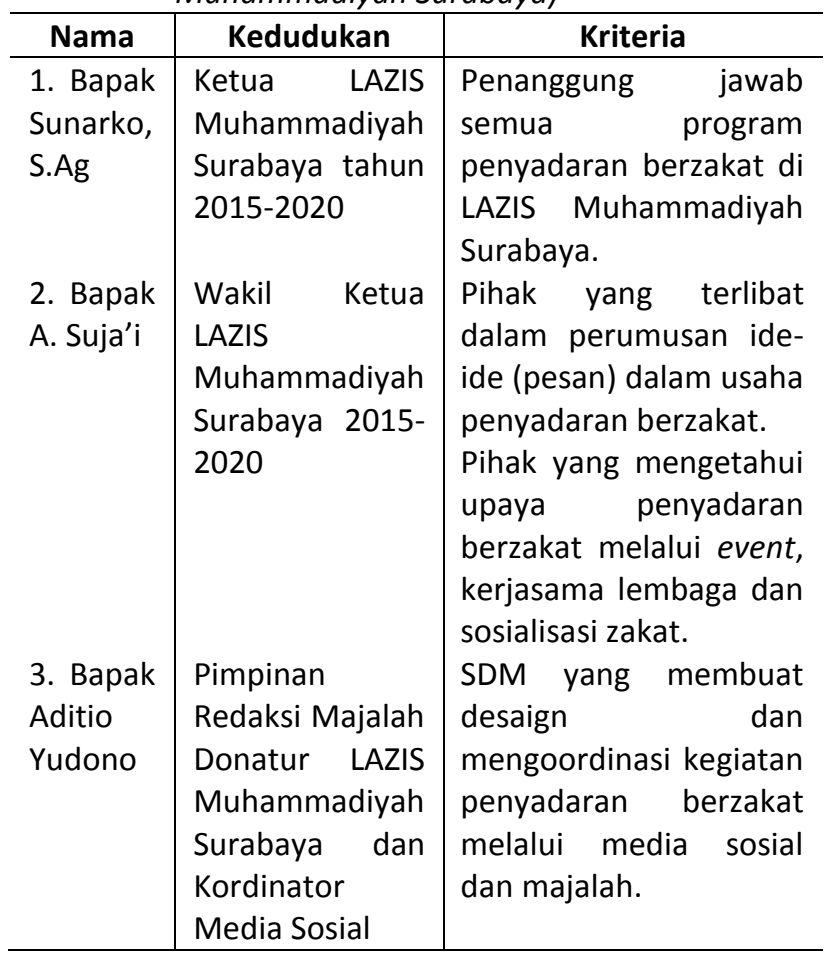

\footnotetext{
${ }^{37}$ Ibid, 246.
} 


\section{Perumusan}

\section{Penyadaran Berzakat}

\section{Menentukan Tujuan Strategi Penyadaran Berzakat}

Sebelum merancang strategi penyadaran berzakat, Pengurus LAZIS Muhammadiyah Surabaya melakukan penentuan tujuan dakwah, yang meliputi penentuan sasaran kegiatan penyadaran berzakat dan mengongkretkan efek yang diharapkan dari kegiatan penyadaran berzakat. Sasaran utama audiens penyadaran berzakat lebih pada anggota Ormas Muhammadiyah, akan tetapi tidak menutup kemungkinan untuk menampilkan pesan-pesan yang bersifat umum agar dapat diterimah masyarakat secara luas.

"Terus terang aja memang kita bertahap yah, itu, jadi karena penyadaran berzakat itu memang secara ini masih banyak berfokus di internal, di Muhammadiyah sebab selama ini juga belum semua anggota Muhammadiyah yang belum berzakat melalui LAZIS Muhammadiyah sendiri. Selain itu, Jejaring Muhammadiyah sendiri juga masih sangat banyak yaitu PCM-PCM yang masih banyak memiliki potensi zakat. ${ }^{38}$

"Sejauh ini sasaran donatur LAZIS Muhammadiyah Surabaya 60\% masih interen (anggota Muhammadiyah), 40\%nya eksternal. Sehingga, penyadaran berzakatnya banyak fokus di anggota Muhammadiyah sendiri. Kebanyakan donatur tertarik dengan Muhammadiyah yah kan karena $60 \%$ kan interen ya, jadi ikatan emosionalnya agak tinggi. yang $40 \%$ itu kedekatan pertemanan, kalau yang tau sendiri sedikit lah itu yah paling 5\% lah, yah

\footnotetext{
${ }^{38}$ Suja'i (Wakil Ketua LAZIS Muhammadiyah Surabaya), Wawancara oleh Penulis, Gedung Dakwah, 27 Mei 2016, pukul 16.00-17.00.
}

lewat perteman itu lah yang paling banyak. ${ }^{\prime 39}$

"Misalnya medsos juga untuk menunjukan sebagai ormas Muhammadiyah. yah biasalah, kalau ormas kan pasti panutanya kan ditampilkan, program - programnya juga ditampilkan. Sehingga, harapannya dari ormas Muhammadiyah sendiri mau juga menyalurkan zisnya melalui LAZIS Muhammadiyah Surabaya."

Dari data di atas menunjukan bahwa pertimbangan memilih anggota Muhammadiyah sebagai audiens sasaran penyadaran berzakat antara lain: (1) ada modal jaringan atau kedekatan ikatan pertemanan yang memudahkan melakukan penyadaran berzakat; (2) potensi anggota Muhammadiyah juga masih banyak yang belum menyalurkan zakatnya melalui LAZIS Muhammadiyah Surabaya; (3) kondisi internal yang belum memungkinkan mentarget berbagai jenis kalangan, oleh karenanya secara bertahap strategi penyadaran berzakatnya lebih diarahkan pada anggota Muhammadiyah.

Berdasarkan wawancara yang dilakukan, LAZIS Muhammadiyah memiliki beberapa kategori tujuan dalam kegiatan penyadaran berzakat yaitu (1) menyadarkan masyarakat bahwa bentuk kewajiban zakat itu bermacam-macam, bukan hanya zakat fitrah saja, menunjukan bahwa zakat itu wajib, dan memberikan informasi bagaimana menyalurkan yang tepat; (2) menyadarkan bahwa zakat adalah salah satu perintah yang wajib ditunaikan sebagaimana salat dan haji, sebagai bagian dari rukun iman.

\footnotetext{
${ }^{39}$ Aditio (Kordinator Media Sosial), Wawancara oleh Penulis, Wisata Kuliner Mulyorejo Surabaya, 1 Juni 2016, pukul 19.00-21.00. 40 Ibid.
} 
"Orientasi penyadaran berzakat lebih pada aspek pemahaman tentang pentingnya kita berzakat, karena itu kan rukun Islam juga kan sama dengan sholat. Kan, umat Islam cenderung melalaikan yang zakat itu. Kita penyadaranya gak zakat ya sama aja meninggalkan salat. Gambaranya seperti itu, kan sama-sama rukun Islamnya, kenapa haji itu dilaksanakan, zakat kok ndak. Selain itu, kita juga ingin manyadarkan bahwa zakat mal itu kan sama saja dengan fitrah kan. Padahal zakat itu kan macem-macem, penyadaranya juga ya gak ini, jenis-jenis zakatnya kan macemmacem, pertanian, peternakan, emas. ${ }^{\prime 41}$

"Kan, umat Islam cenderung melalaikan yang zakat itu. Kita tujuannya beri penyadaranya bahwa gak zakat ya sama aja meninggalkan salat. gambaranya seperti itu, kan sama-sama rukun Islamnya, kenapa haji dan salat itu begitu antusias dilaksanakan, zakat kok ndak."

"Selama ini kita memilih media sosial Whatsapp, Facebook, dan blog untuk menyadarkan berzakat dan membangun kepercayaan pada donatur. Kalau whatsapp kan untuk donatur, kalau facebook dan blog sasarannya untuk umum. WA itu rata-rata kelas menengah, karena kebanyakannya donatur tetap. Wa cukup bisa berperan menyadarkan berzakat dan meningkatkan kepercayaan masyarakat kelas menengah karena kita kan bisa panjang lebar, dialog langsung itu kan ada yang tanya-jawab masalah zakat." 43

\section{Melakukan Analisis Situasi}

Sebelum melakukan perumusan strategi penyadaran berzakat, LAZIS Muhammadiyah mengadakan rapat untuk mengetahui kondisi internal ataupun lingkungan terkait yang memengaruhi usaha penyadaran dan penumbuhan kepercayaan masyarakat. Hasil analisis situasi tersebut antara lain: Pertama,

\footnotetext{
$41 \mathrm{Ibid}$

$42 \mathrm{Ibid}$

43 Ibid.
}

Surabaya merupakan salah satu kota besar, memiliki perkembangan teknologinya yang cenderung cepat. Masyarakat Surabaya hampir semuanya memiliki smartphone dan banyak tergabung dalam grup-grup dunia maya seperti whatsapp (WA) dan facebook. Awalnya LAZIS Muhammadiyah hanya melakukan penyadaran berzakat melalui majalah dan koran untuk memperkenalkan diri ke masyarakat Surabaya, tetapi karena perubahan zaman beralih ke era digital, hampir semua memiliki smartphone, maka pengurus memutuskan harus ada proses adaptasi dalam rangka menyadarkan masyarakat berzakat. Berdasarkan penuturan Aditio (kordinator media sosial), awalnya hanya dia yang memiliki kesadaran perlunya menggunakan media sosial. Saat itu media sosial belum sepopuler sekarang, sehingga sangat sedikit pengurus yang memahami peran media sosial. Namun, dengan proses diskusi tentang kondisi perkembangan berbagai media sosial seperti: WA, Linked dan lain-lain, akhirnya menumbuhkan kesadaran pada sebagian pengurus bahwa media sosial memiliki peluang berperan sangat penting dalam melakukan penyadaran berzakat dimasyarakat di era digital saat ini. Bahkan, beberapa media sosial yang digunakan oleh LAZIS Muhammadiyah saat ini sangat beragam dan bukan hanya diinisiatori oleh Aditio saja. Kedua, analisis situasi terkait potensi Sumber Daya Manusia (SDM) yang memungkinkan bergerak melakukan penyadaran berzakat dan penumbuhan kepercayaan dengan menggunakan berbagai media. Pengurus LAZIS Muhammadiyah Surabaya, mengidentifikasi ketersediaan SDM untuk mengelola media sosial, majalah ataupun untuk terjun ke berbagai Pimpinan Cabang 
Muhammadiyah (PCM) dan pengajian untuk melakukan sosialisasi. Dari hasil analisis situasi tersebut dijadikan pijakan dalam menetapkan media yang dipilih dan menetapkan intensitas untuk melakukan penyadaran berzakat. Ketiga, analisis situasi terkait dengan karakteristik objek sasaran penyadaran berzakat. Selama ini pengurus melihat besarnya potensi jaringan LAZIS Muhammadiyah dari ormas Muhammadiyah. Sehingga, yang menjadi sasaran penyadaran berzakat adalah anggota Muhammadiyah. Sebagian besar anggota Muhammadiyah hidup di perkotaan, termasuk banyak pula yang hidup di kota Surabaya. Kebanyakan warga Muhammadiyah tergolong kelas menengah muslim yang memiliki ekonomi cukup dan moral berderma yang tinggi. Warga Muhammadiyah sangat cerdas memilih kemana akan menyalurkan zakat, infak dan sedekahnya. Hal ini menjadi peluang sekaligus tantangan bagi LAZIS Muhammadiyah agar dapat meyakinkan warga Muhammadiyah bahwa LAZIS Muhammadiyah Layak menjadi mitra utama warga Muhammadiyah. ${ }^{44}$

"Jejaring Muhammadiyah sendiri juga masih sangat banyak yaitu PCM-PCM yang masih banyak memiliki potensi zakat. ${ }^{\prime 45}$

\section{Merumuskan Pesan (Materi) Penyadaran Berzakat}

Setelah memahami karakteristik audience LAZIS Muhammadiyah Surabaya yang kebanyakan adalah anggota Muhammadiyah, dengan karakteristik antara lain: religius, tergolong kelas

44 LAZIS Muhammadiyah Kota Surabaya, Majalah Donatur LAZIS Muhammadiyah, Edisi 101 Tahun IX, Sya'ban 1437, (Surabaya : LAZIS Muhammadiyah, Mei 2016), 13.

${ }^{45}$ Suja'i, Wawancara oleh Penulis, Surabaya, 27 Mei 2016, pukul 16.00-17.00. menengah muslim yang terdidik dan memiliki ikatan atau identifikasi diri sebagai anggota Muhammadiyah, maka LAZIS Muhammadiyah mengangkat beberapa pesan antara lain: Pertama, menonjolkan pesan-pesan penyadaran yang bersifat dalil Alquran dan hadis. Khususnya untuk mengedukasi masyarakat tentang kewajiban berzakat sebagai salah rukun iman, memiliki ketentuan-ketentuan yang harus dipahami dan menekankan pada pentingnya menunaikan zakat mal sebagaimana perintah wajib lainnya (kewajiban zakat fitrah, salat, haji). Hal ini dikarenakan masih banyak pula di kalangan masyarakat yang belum memahami dengan baik ketentuan-ketentuan dalam berzakat.

"Dari aspek pemahaman zakat kita angkat, tentang dalil juga, aspek pemahaman tentang pentingnya kita berzakat juga. Aditio menjelaskan: karena zakat itu kan rukun Islam juga kan sama dengan salat. .... Menunjukan dalil-dalil Alquran dan Hadis ke masyarakat yang menunjukan bahwa zakat itu kan macem-macem. Sehingga, kita penyadaranya juga ya menunjukan jenis-jenis zakatnya kan macem-macem, pertanian, peternakan, emas." $" 46$

Kedua, mengangkat pesan-pesan yang menunjukan kebermanfaatan zakat bagi individu dan sosial, khususnya dengan membangun paradigma bahwa zakat bukan hanya dipandang sebagai kewajiban melainkan juga sebagai kebutuhan. Hal ini mempertimbangkan karakteristik masyarakat muslim kelas menengah merupakan masyarakat terdidik, yang baru akan memiliki kesadaran terhadap berzakat jika zakat itu memiliki kemanfaatan bukan hanya bagi sosial namun juga individu dan

\footnotetext{
${ }^{46}$ Aditio, Wawancara oleh Penulis, Surabaya, 1 Juni 2016.
} 
keluarga. Sehingga, dengan begitu zakat menjadi kebutuhan pribadi untuk ditunaikan dengan baik.

"Materi penyadaran berzakat, yah yang mudah kena, kan disana ada banyak ayat ayat Allah, janji-janji Allah. Terus, yang pertama kali diangkat itu ya, dalil Syar'i ya, Alquran, Hadis. Kedua, kemanfaatan, manfaat itu ya untuk dia, manfaat zakat untuk pribadi itu apa sih, ditunjukan $a, b, c$, $d, e, f$, gitu. Jadi pertama anjuran dari Syar'i, yang kedua manfaat untuk muzaki..eh, apa yang berzakat itu sendiri. Dan yang ketiga dampak sosialnya. Begitu, tapi sebenarnya stresingnya yang paling kita tekankan itu adalah dampak bagi dia. ${ }^{\prime 47}$

"nah iya, artinya kan harus ditunjukan dampak positif zakat terhadap dirinya, contoh terhadap keluarganya. Jadi syetan itu masuk itu melalui salah satunya berkumpul dengan manusia itu kan banyak dia bisa masuk lewat jalan darah. Bisa, ngapunten, ketika seseorang suami istri itu berkumpul kalau itu tidak anu syaitan itu bisa ikut-ikut di sana. Terus, ketika makan, ketika kita tidak mengucapkan bismillah nah itu. Nah salah satunya kalau itu ada harta yang tidak dizakati ada 2 katanya. Jadi syaitan itu di situ ikut berperan itu dicampur antara harta yang batil dan kemudian dampaknya itu kepada keluarganya, karena itu harus berzakat. Karena harta kita itu kalau tidak dizakati kan berarti bercampur antara yang halal dan yang haram. Nah itu dampaknya bagi keluarga luar biasa. Selain, sekali lagi itu dampaknya. Manfaatnya, yang diberikan oleh Allah bagi orang berzakat juga luar biasa itu. Nah, proses penyadaran bahwa ke individu sendiri, sebetulnya yang paling, paling mengena itu di situ. Terus kita sadarkan juga sebetulnya harta ini tidak kita bawa mati. Nah, itu padahal mati sebuah kepastian dan harta itu tidak dibawa itu juga sebuah kepastian, terus sampeyan nyimpen harta gawe opo? opo maneh saiki sampeyan ngoyoh-ngoyoh,

\footnotetext{
${ }^{47}$ Suja'i, Wawancara oleh Penulis, Surabaya, 27 Mei 2016.
}

oleh harta, dikumpulno terus meninggal, ehm gawe opo hartane?." 48

Selain itu ya, kita angkat juga aspek kemanusiaan. Zakat kan manfaatnya ini, ada manfaatnya untuk kemanusiaan, pemberdayaan, untuk dakwah dan lainlain." ${ }^{\prime \prime 9}$

Contoh materi (pesan) penyadaran yang diangkat untuk menekankan aspek kebermanfaatan berzakat bagi individu, seperti: (1) menunjukan contoh-contoh konkret dampak bagi individu yang memberi nafkah keluarganya dengan rezeki yang belum jelas haram dan halalnya karena belum dizakati, maka setan akan mudah mendekat pada keluarganya; (2) menunjukan bahwa manusia memiliki kepastian akan mati dan harta tidak akan dibawa mati maka bila tidak dizakati maka untuk apa harta yang dimiliki tersebut dan contoh-contoh manfaat lainnya; informasi kemuliaan zakat bagi muzaki (dengan menunjukan profil donatur/muzaki yang sukses dan bahagia dalam hidup karena berzakat; (4) menunjukan kemanfaatan zakat dengan menampilkan pengaruh zakat bagi para mustahik melalui cerita detail sosok yang mendapat bantuan dari zakat LAZIS Muhammadiyah Surabaya. ${ }^{50}$ Pesan penyadaran tersebut senantisa diangkat dalam serangkaian kegiatan (cara) penyadaran yang dilaksanakan oleh LAZIS Muhammadiyah Surabaya.

"Rencana materi yang akan ditampilkan juga informasi manfaat zakat bagi yang menerimanya (mustahiknya). Misalnya yang terima beasiswa, menerima bantuan apa itu, biar teman-teman yang menagih zakat itu mengeksplor manfaatnya kepada

\footnotetext{
48 Ibid.

${ }^{49}$ Ibid.

${ }^{50}$ Ibid.
} 
donatur, dan mewawancarai manfaat bagi mustahiqnya. Kalau ada manfaatnya apa ya ditanyai lah, dicatet-dicatet dishare lewat tulisan. ya, kita angkat manfaat zakat dari aspek kemanusiaan. Zakat kan manfaatnya ini banyak, ada manfaatnya untuk kemanusiaan, pemberdayaan, untuk dakwah dan lain-lain. Saat ini mulai ditampilkan, eh tentang penerima manfaat itu komentarnya apa ditampilkan di konten mustahiq. Misalnya yang terima bea siswa, menerima bantuan apa itu, biar temanteman yang menagih itu mengeksplor, wawancarai-lah. Kalau ndak manfaatnya apa ditanyai lah, dicatet-dicatet di share. Selain itu bisa konten muzaki-lah, kan biasanya mustahiqnya saja seperti: fakir, miskin." ${ }^{\prime 1}$

"Kami merencanakan bahwa dalam tiap sosialisasi zakat langsung ke masyarakat itu, harus diiringi juga kegiatan APD LAZIS Muhammadiyah, (Aksi Peduli D\}u'afa). Tidak hanya sosialisasi saja, tapi kita buktikan dengan pemberian sembako orang-orang duafa yang di sekitar kita. Sehingga juga menarik. Oh, aku dijak berzakat iku ternyata juga diberikan kepada mereka. Uang ku iku tak kekno LAZIS iku kanggo opo yo." ${ }^{\prime 52}$

"Misalnya lagi dalam pengajian yang diselenggarakan oleh Muhammadiyah, LAZIS Muhammadiyah Surabaya bukan hanya menyampaikan sosialisasi tentang nilai penting berzakat melalui lisan, melainkan juga memiliki rencana menggugah hati masyarakat dengan pembagian bantuan secara langsung untuk para disabilitas. Program bantuan untuk para disabilitas ini merupakan salah satu program utama LAZIS Muhammadiyah Surabaya. LAZIS Muhammadiyah Surabaya dengan dana zakat dan infak yang terkumpul membagikan seribu kursi roda kepada para penyandang disabilitas dan pembagian ini dilaksanakan di setiap pengajian ahad yang diselenggarakan oleh organisasi Muhammadiyah. Dengan cara seperti ini masyarakat muslim akan

\footnotetext{
51 Ibid.

${ }^{52}$ Sunarko, Wawancara oleh Penulis, Surabaya, 20 Mei 2016.
}

mengetahui secara langsung manfaat zakat yang ditunaikannya. ${ }^{53}$

Lazismu Surabaya

25 Februart : a
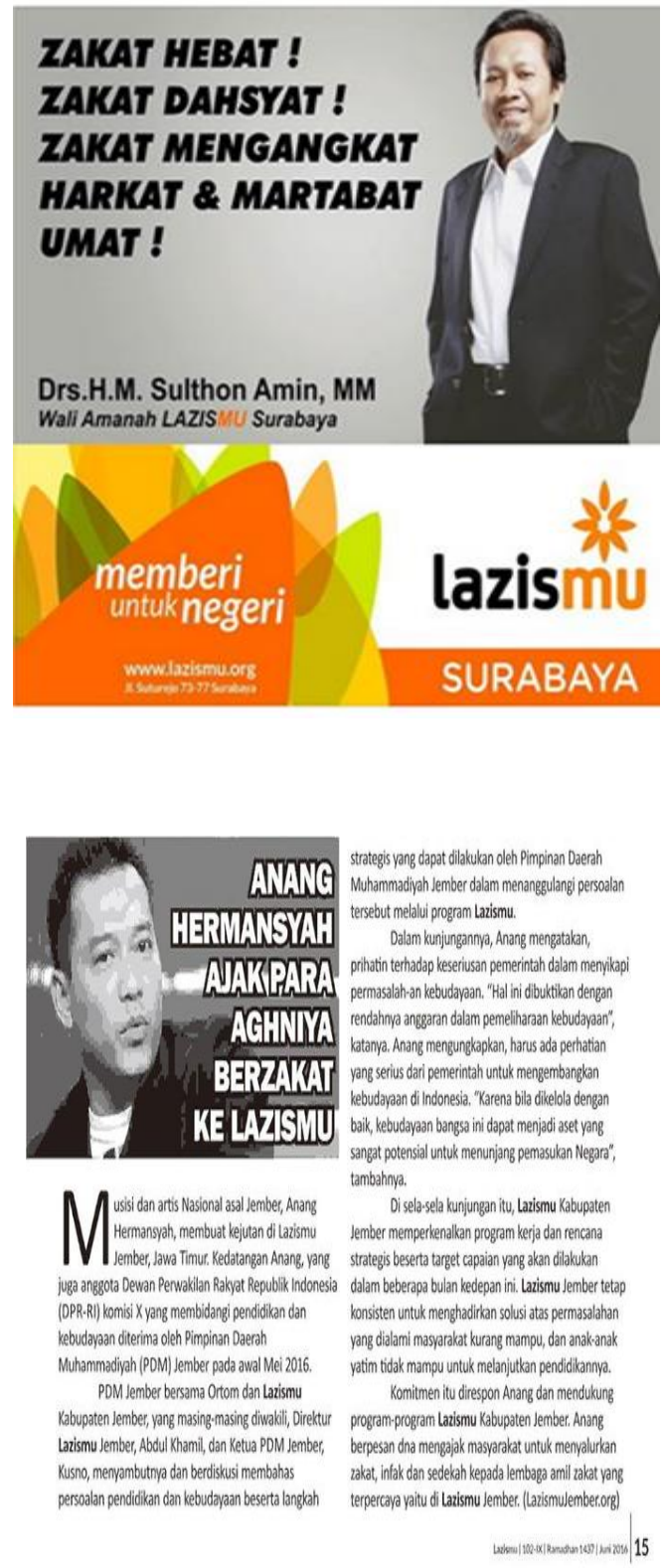

Gambar 1 - Beberapa Figur yang Ditampilkan di Facebook dan Majalah untuk Mengajak Berzakat di LAZIS Muhammadiyah

53 Ibid. 


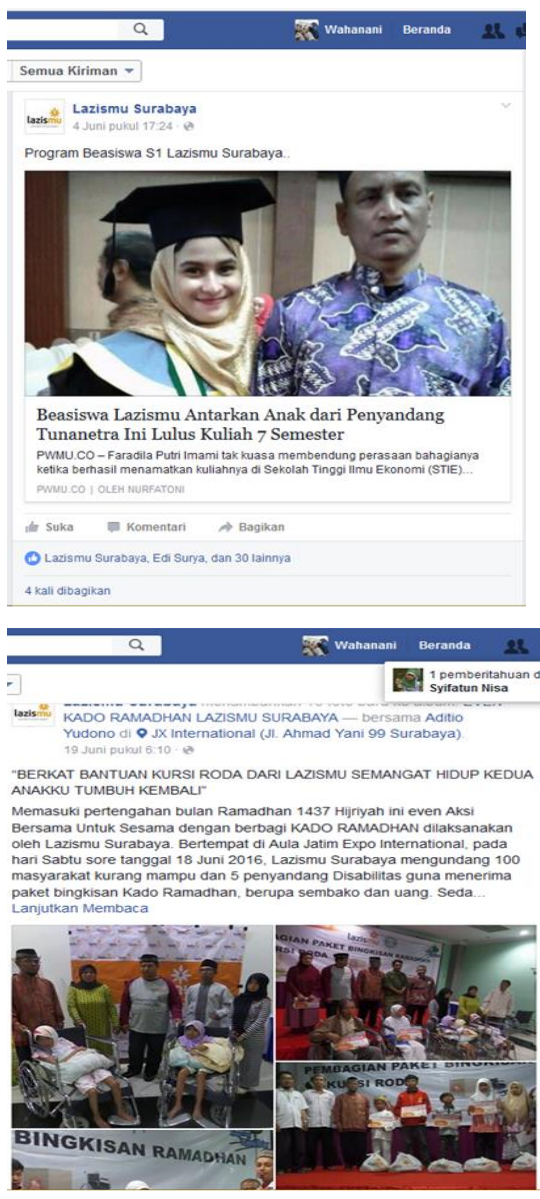

Gambar 2

Tampilan Facebook Manfaat Zakat Bagi

Mustahik
Selain itu, LAZIS Muhammadiyah juga membuat informasi-informasi yang bersifat mengingatkan berzakat, baik berupa tagline-tagline yang ada di blog, facebook, whatsapp LAZIS Muhammadiyah Surabaya antara lain: "Zakatku Amal Kebajikanku," "Yang Hebat Yang Berzakat," "Zakat memberdayakan Sesama," "Jangan Menuhankan Harta," dan "Tidak Membayar Zakat = Koruptor," Berbagai untuk Sesama Tak Perlu Menunggu Kaya."

Secara umum pesan-pesan penyadaran berzakat dan penumbuhan kepercayaan yang digunakan oleh LAZIS Muhammadiyah Surabaya dapat dilihat pada tabel 2 .

Tabel 2

Rencana Pesan Penyadaran Berzakat dan Penumbuhan Kepercayaan Pada LAZIS Muhammadiyah Surabaya

\begin{tabular}{|c|c|c|c|c|}
\hline No & Tujuan & Tujuan Dakwah & Materi Dakwah & $\begin{array}{l}\text { Penyajian / } \\
\text { Metode }\end{array}$ \\
\hline 1. & $\begin{array}{l}\text { Penyadaran } \\
\text { berzakat. }\end{array}$ & $\begin{array}{ll}\text { 1. } & \text { Menyadarkan dalil atau } \\
\text { landasan kewajiban berzakat. } \\
\text { 2. } \\
\text { Memberikan informasi } \\
\text { tentang berbagai jenis zakat. } \\
\text { 3. } \begin{array}{l}\text { Memberikan informasi cara } \\
\text { menunaikan berzakat. }\end{array} \\
\text { 4. } \begin{array}{l}\text { Menunjukan aspek manfaat } \\
\text { berzakat. }\end{array} \\
\text { 5. } \begin{array}{l}\text { Mengingatkan untuk segera } \\
\text { menunaikan zakat. }\end{array}\end{array}$ & \begin{tabular}{|ll} 
1. & Informasi dalil ayat \\
& Alquran dan hadis sebagai \\
& dasar kewajiban berzakat. \\
2. & Informasi kemanfaatan \\
& zakat bagi Mustahik dan \\
& Muzaki \\
3. Informasi cara & menunaikan berzakat. \\
4. & Informasi jenis zakat.
\end{tabular} & $\begin{array}{ll}\text { 1. } & \text { Ceramah } \\
\text { 2. Artikel. } \\
\text { 3. Karikatur. } \\
\text { 4. Tabel } \\
\text { ketentuan } \\
\text { berzakat. } \\
\text { 5. Video } \\
\text { 6. Tagline } \\
\text { 7. Aksi langsung }\end{array}$ \\
\hline
\end{tabular}

\section{Menentukan Media Penyadaran berzakat dan Penumbuhan Kepercayaan}

Dari proses analisis situasi serta penetapan audiens sasaran, LAZIS Muhammadiyah memilih media-media yang memungkinkan digunakan untuk penyadaran berzakat. Jika awalnya LAZIS Muhammadiyah Surabaya hanya menggunakan majalah dan koran untuk penyadaran berzakat di masyarakat. Namun, saat ini LAZIS Muhammadiyah sudah tidak lagi menggunakan koran. LAZIS Muhammadiyah memutuskan untuk 
menggunakan media sosial, majalah, kerjasama dengan mitra LAZIS Muhammadiyah Surabaya, event yang berkerjasama dengan Organisasi Kemasyarakatan (Ormas) Muhammadiyah, dan meningkatkan intensitas sosialisasi langsung ke PCM-PCM Ormas Muhammadiyah. Perencanaan media penyadaran berzakat tersebut secara umum sebagai berikut:

a) Sosialisasi ke masyarakat

Kegiatan sosialisasi ke masyarakat dalam rangka penyadaran berzakat, yang dilaksanakan oleh LAZIS Muhammadiyah adalah dengan mengadakan kegiatan sosialisasi melalui cabang-cabang yang dimiliki organisasi Muhammadiyah Surabaya. Kegiatan sosialisasi ini dilaksanakan sebulan sekali. Hal tersebut berdasarkan hasil wawancara dengan informan Suja'i sebagai berikut:

"Kalau penyadaran lain juga ada yang di masyarakat, tidak hanya di medsos. Itu secara penyadaran kita itu selalu keliling ke PCM-PCM untuk penyadaran. Jadi media penyadaran kita itu lewat PCM itu satu bulan 1 kali, ini mau kita tingkatkan jadi 2 kali. Jadi, 1 bulan itu 2 kali kita ke PCM untuk sosialisasi. Ke kecamatan atau ke lembaga misalnya ke lembaga haji itu, penyadaran tentang zakat. Alhamdulillah dengan itu ada 20 orang yang bersedia jadi donatur. ya, dulu di PCM Sutorejo ini ada 30 lebih yang masuk jadi donatur. Jadi penyadaran-penyadaran kita yang tidak lewat medsos itu namanya kita sosialisasi itu biasanya satu bulan 2 kali. ${ }^{\prime 54}$

Sosialisasi penyadaran berzakat yang dilaksanakan oleh LAZIS Muhammadiyah Surabaya ini bukan hanya menyampaikan secara lisan, tetapi juga disertai dengan penyelenggaraan kegiatan baksos langsung

\footnotetext{
${ }^{54}$ Suja'i, Wawancara oleh Penulis, Surabaya, 20 Mei 2016.
}

kepada duafa. Kegiatan aksi baksos pada duafa ini, menurut ketua dan wakil ketua LAZIS Muhammadiyah Surabaya dapat meningkatkan kesadaran berzakat masyarakat kelas menengah (khususnya anggota Muhammadiyah di tingkat ranting), sebab dari proses ini masyarakat dapat merasakan langsung bahwa dana yang dikeluarkan untuk zakat, infak dan sedekah dapat bermanfaat pada masyarakat. Dari proses sosialisasi dan aksi baksos yang dilaksanakan oleh LAZIS Muhammadiyah Surabaya, banyak donatur yang kemudian bergabung menjadi donatur tetap yaitu 20-30 orang pada tiap sesi sosialisasi yang dilakukan.

"Sebetulnya lebih cepat kalau orang ikut berzakat itu kalau kita menyadarkan secara langsung, nah kumpulkan. Tapi bukan selingan ya. Jadi memang kita langsung secara khusus kita tampil satu jam, jadi ada tanya jawab, interaksi, masyarakat kan sangat senang kalau diajak komunikasi dua arah, setelah itu, biasanya itu lebih cepat dibandingkan medsos." "Cuma sekali lagi intensitas kita ini memang satu bulan ini maksimal masih 2 kali. Karena apa, karena sebetulnya kalau sdmnya banyak, bisa sebetulnya lebih banyak lebih cepet gitu dengan media sosialisasi. Tapi kemampuan kita masih terbatas"

"Sosialisasi kemasyarakat secara langsung lebih cepat menyadarkan masyarakat karena ada aksi peduli duafa. Istilahnya di dalam kegiatan sosialisasi itu ada teori dan praktik kemanfaatan zakat secara langsung."

Berdasarkan data di atas, dapat ditarik kesimpulan bahwa kegiatan sosialisasi zakat secara langsung ini dinilai oleh sebagian besar pengurus LAZIS Muhammadiyah Surabaya, lebih cepat

\footnotetext{
55 Ibid.

56 Sunarko, Wawancara oleh Penulis, Surabaya, 20 Mei 2016.
} 
dalam membangun kesadaran masyarakat untuk menyalurkan zakat, infak dan sedekah melalui LAZIS Muhammadiyah dibandingkan dengan media yang selainnya. Sosialisasi berzakat secara langsung lebih cepat dalam membentuk kesadaran masyarakat karena masyarakat tahu secara langsung lembaga zakatnya dan aksi penyantunannya. Namun, karena penyadaran berzakat membutuhkan banyak SDM untuk dapat intens ke berbagai kalangan masyarakat, akhirnya kegiatan sosialisasi ini belum dapat berjalan optimal dan cepat.

b) Kegiatan pengajian

Cara lain yang dipilih oleh LAZIS Muhammadiyah Surabaya dalam rangka penyadaran berzakat dan menumbuhkan kepercayaan masyarakat adalah melalui event. Event yang dipilih adalah kegiatan pengajian ahad yang selalu diadakan oleh organisasi Muhammadiyah pada ahad ke-4 tiap bulannya. Pengajian ini sangat banyak diikuti oleh masyarakat umum ataupun pengurus organisasi Muhammadiyah mulai tingkat ranting sampai daerah. Pengajian ini sangat menarik karena biasanya mengundang tokoh-tokoh nasional ataupun pimpinan pusat Muhammadiyah.

Dalam pengajian yang diselenggarakan oleh Muhammadiyah, LAZIS Muhammadiyah Surabaya bukan hanya menyampaikan sosialisasi tentang nilai penting berzakat melalui LAZIS Muhammadiyah, melainkan juga memberikan bantuan secara langsung pada penyandang disabilitas tiap bulannya. LAZIS Muhammadiyah menargetkan pembagian seribu kursi roda pada penyandang disabilitas.

Selain dengan pengajian ahad yang secara rutin diselenggarakan melalui berkerjasama dengan PDM (Pimpinan Daerah Muhammadiyah), kegiatan penyadaran berzakat juga dilakukan pengurus saat para pengurus mengisi ceramah-ceramah agama di masyarakat. Bahkan beberapa pengajian juga bersifat tidak terprogramkan. Hal ini dikarenakan, banyak dari pengurus yang juga dai sehingga dapat menyampaikan materi keislaman di masyarakat dan di dalamnya dapat disampaikan pula materi tentang kewajiban berzakat. Pengurus juga bekerjasama dengan Korp Mubalig Muhammadiyah agar memiliki kesempatan yang lebih luas untuk menyadarkan berzakat masyarakat dan menumbuhkan kepercayaan pada LAZIS Muhammadiyah Surabaya.

"Dalam Pengajian juga ada kegiatan penyadaran berzakatnya. Kadang-kadang begini mbak. Ada kebetulan pak Ja'i, saya, pak Hakim, pak. Anam ini kan juga aktif ceramah di masjid-masjid Muhammadiyah. Saya tadi kan sebenarnya kosong jadwal saya, dimintai ngisi jumat langsung di Masjid Dillah. Yah itu tema-tema kita ya tentang zakat, sekali-kali nyebut ada LAZIS Muhammadiyah, Iha, itu juga kan penyadaran masyarakat. Ndak papa kan sebut merk. Makanya kita juga sinergi dengan KMM itu, KMM itu singkatan dari Korp Mubaligh Muhammadiyah, nanti ada beberapa mubaligh yang kita jadikan duta untuk menyampaikan tema-tema tentang zakat itu, dalam rangka kita percepatan untuk mengajak muzaki." ${ }^{\prime 57}$

"Yang pengajian tidak terprogram, ya kadang-kadang kita diundang ndadak, Seperti di masjid sana, ya itu kita memiliki rencana untuk selalu membawa majalah saat diminta berceramah dimasyarakat untuk menunjang penyadaran berzakat. Kemarin aja kita disuruh ngisi pengajian ibu-ibu, contoh ya di itu ya kita bawa majalah, dan menjelaskan tentang Zakat, LAZIS Muhammadiyah dan alhamdulillah ya

\footnotetext{
57 Ibid.
} 
ada dapat donatur yang mau berzakat mal. ${ }^{1158}$

c) Majalah LAZIS Muhammadiyah

Surabaya

Upaya berikutnya yang dilakukan oleh

LAZIS Muhammadiyah adalah melalui majalah LAZIS Muhammadiyah. Majalah LAZIS Muhammadiyah menampilkan berbagai kegiatan yang dilaksanakan oleh LAZIS Muhammadiyah Surabaya di bulan sebelumnya, menunjukan program utama LAZIS Muhammadiyah, dan juga memberikan ajakan-ajakan untuk menyalurkan zakat, infak, dan sedekah melalui LAZIS Muhammadiyah. Majalah ini merupakan salah satu media utama untuk membangun hubungan (kepercayaan) yang baik, khususnya untuk para donatur tetap LAZIS Muhammadiyah Surabaya. Oleh karena itu, di dalam majalah dihadirkan berbagai konten bukan hanya untuk penyadaran berzakat namun juga untuk menumbuhkan kepercayaan berzakat masyarakat.

Bagian-bagian dalam majalah yang merupakan upaya untuk menumbuhkan kepercayaan masyarakat, ditunjukan dari: adanya laporan keuangan bulanan, adanya angket donatur serta menunjukan daftar nama-nama donatur baru LAZIS Muhammadiyah Surabaya. Laporan keuangan ditampilkan tiap bulan di bagian akhir majalah untuk menunjukan transparansi keuangan, serta menunjukan bahwa saldonya tidak terlalu besar. Angket donatur berfungsi untuk melihat respon donatur terhadap pelayanan LAZIS Muhammadiyah Surabaya, sehingga hal ini menjadi acuan bagi LAZIS Muhammadiyah Surabaya untuk meningkatkan kualitasnya.

\footnotetext{
58 Ibid.
}

Majalah LAZIS Muhammadiyah sebagai media utama dalam penyadaran berzakat, secara jangkauan kurang maksimal karena hanya digunakan untuk donatur ataupun untuk orang-orang yang berminat menjadi muzaki. Oleh karenanya, dalam rangka memperluas jangkauan komunikasi penyadaran berzakat dan menumbuhkan kepercayaan masyarakat pada masyarakat muslim kelas menengah maka LAZIS Muhammadiyah mengintegrasikan majalah ini dengan media sosial. Majalah LAZIS Muhammadiyah Surabaya bukan hanya dapat kita nikmati dengan membaca bentuk fisiknya, tetapi juga dapat diakses melalui facebook.

Dalam facebook LAZIS Muhammadiyah Surabaya, ditampilkan majalah secara lengkap mulai halaman awal sampai dengan akhir, hal ini agar yang menikmati majalah bukan hanya kalangan donatur tetapi juga masyarakat secara luas. Bahkan, dari melihat facebook banyak yang kemudian tertarik untuk mendapatkan majalahnya secara fisik, untuk mendapatkan majalah secara rutin dalam bentuk fisik, maka otomatis harus menjadi donatur pada LAZIS Muhammadiyah Surabaya. Integrasi majalah dan media sosial yang digunakan oleh LAZIS Muhammadiyah Surabaya juga dapat dilihat dari isi majalah yang sama dan setema dengan yang ditampilkan di media sosial.

d) Program hubungan masyarakat

LAZIS Muhammadiyah Surabaya juga menggunakan cara-cara hubungan masyarakat (kerja sama) dengan berbagai lembaga lainnya dalam rangka untuk memperluas komunikasi penyadaran berzakat pada masyarakat. Langkah- 
langkah yang dilaksanakan antara lain berkerjasama dengan Kelompok Bimbingan Ibadah Haji (KBIH) Muhammadiyah untuk melakukan sosialisasi pada calon jemaah haji untuk menyadarkan berzakat dan mendorong jemaah untuk menyalurkan zakat, infak dan sedekah secara tepat melalui LAZIS Muhammadiyah. Selain itu, kerja sama dengan dinas-dinas pemkot juga dilaksanakan dalam rangka meningkatkan donatur yang membantu melalui LAZIS Muhammadiyah Surabaya. Ketua LAZIS Muhammadiyah secara aktif menyosialisasikan pada rekan-rekannya di dinas-dinas pemkot tentang pentingnya menunaikan kewajiban berzakat. Tidak sedikit donatur zakat LAZIS Muhammadiyah yang merupakan masyarakat yang berprofesi sebagai Pegawai Negeri Sipil (PNS) dari dinas sosial dan dinas-dinas lain yang merupakan hasil dari kegiatan sosialisasi penyadaran berzakat dan hubungan masyarakat dengan dinas tersebut.

\section{e) Media sosial}

Media lain yang berperan cukup penting dalam upaya penyadaran berzakat dan menumbuhkan kepercayaan yang dimiliki oleh LAZIS Muhammadiyah adalah media sosial. Beberapa media sosial yang digunakan oleh LAZIS Muhammadiyah Surabaya antara lain: website LAZIS Muhammadiyah pusat, Blog LAZIS Muhammadiyah Surabaya, facebook LAZIS Muhammadiyah Surabaya, linked dan whatsapp. Blog digunakan untuk menunjukan berbagai aspek dari lembaga LAZIS Muhammadiyah Surabaya, mulai dari: profil (kontak) LAZIS Muhammadiyah, program, berbagai informasi zakat ataupun informasi cara penyaluran berzakat yang praktis melalui rekening. facebook sebagai media penyadaran berzakat pada para donatur yang bersifat interaktif, dapat menampilkan update kegiatan-kegiatan aktual yang dilaksanakan oleh LAZIS Muhammadiyah Surabaya, tanya jawab zakat, serta dapat menyajikan majalah LAZIS Muhammadiyah setiap bulannya secara online, sehingga hal ini dapat menumbuhkan kepercayaan masyarakat terhadap LAZIS Muhammadiyah Surabaya dengan baik. facebook dalam bentuk grup ini, menjadi media yang bersifat interaktif bagi masyarakat yang ingin tahu lebih dalam tentang LAZIS Muhammadiyah Surabaya dan dapat mengikatkan secara emosional lembaga LAZIS Muhammadiyah Surabaya dengan donatur.

Media sosial yang lainnya yang digunakan LAZIS Muhammadiyah dalam upaya penyadaran berzakat adalah whatsapp. Ketua LAZIS Muhammadiyah membentuk grup whatsapp yang terdiri dari pengurus LAZIS Muhammadiyah Surabaya, tim redaksi majalah dan media sosial, dan para donatur tetap yang berkenan bergabung dalam grup whatsapp LAZIS Muhammadiyah Surabaya. Selain membentuk grup whatsapp secara resmi, menurut pengurus LAZIS Muhammadiyah Surabaya, ada pula grup-grup media sosial lain yang mana pengurus bergabung di dalamnya juga sering menjadi media penyadaran berzakat dan menumbuhkan kepercayaan terhadap LAZIS Muhammadiyah Surabaya.

Berdasarkan hasil wawancara dengan ketua LAZIS Muhammadiyah Surabaya, media sosial bukan hanya sebagai media untuk pemberi informasi tentang zakat tetapi juga 
dapat menggerakan hati para donatur secara cepat dalam membantu menolong masyarakat sekitar melalui LAZIS Muhammadiyah Surabaya. Misalkan saja, pernah suatu ketika LAZIS Muhammadiyah ingin membantu membangun rumah yang hampir roboh di Surabaya. Saat itu, Ketua LAZIS Muhammadiyah Surabaya menginformasikan bahwa ada rumah yang hampir roboh dan mengajak para anggota grup whatsapp untuk berpartisipasi di dalamnya. Hasilnya, cukup cepat dan banyak masyarakat yang bersedia membantu karena informasi yang didapatkan cepat dan jelas melalui whatsapp.

\section{Menentukan Metode yang Digunakan dalam Penyadaran Berzakat di Berbagai Media}

Selain merencanakan pemilihan media penyadaran berzakat, LAZIS Muhammadiyah Surabaya juga melakukan penetapan metode yang tepat untuk dapat menyampaikan materi dakwah secara efektif sesuai dengan karakteristik tiap media yang digunakan dan karakteristik audiens sasarannya, misalnya, dalam media sosial yang berbentuk blog, penyajian pesan adalah dengan menggunakan artikelartikel yang tidak terlalu panjang dan disertai gambar-gambar menarik seperti foto, tabel dan karikatur. Sedangkan jika menggunakan facebook pesan penyadaran berzakat lebih banyak berupa: link-link informasi, video, gambar maupun majalah donatur LAZIS Muhammadiyah Surabaya. Di facebook juga dimungkinkan masyarakat melakukan dialog tanya jawab terkait dengan zakat. Metode yang berbeda-beda, misalnya antara media blog dan facebook tersebut sangat menyesuaikan dengan karakteristik media sosial tersebut.
Majalah lebih banyak menampilkan artikelartikel yang panjang lebar tentang informasi zakat, kemanfaatan zakat baik melalui artikel yang menceritakan profil muzaki dan mustahik, serta layanan tanya jawab zakat yang dijawab secara panjang lebar. Sedangkan, untuk penyadaran yang dilakukan dalam kegiatan event pengajian dan sosialisasi zakat ke PCM-PCM bukan hanya menggunakan pendekatan ceramah namun juga aksi langsung yang akan membuat masyarakat kelas menengah muslim menjadi tersadarkan pentingnya zakat bagi masyarakat.

\section{Memilih Subjek (Dai) untuk Melaksanakan Penyadaran Berzakat}

Selain merancang struktur penangung jawab, LAZIS Muhammadiyah Surabaya juga merencanakan siapa saja dai yang akan melaksanakan penyadaran berzakat. Untuk penyadaran berzakat melalui media sosial, LAZIS Muhammadiyah Surabaya memprioritaskan menghadirkan subjeksubjek yang merupakan muzaki LAZIS Muhammadiyah Surabaya yang sukses dan dikenal oleh kalangan warga Muhammadiyah untuk mengajak berzakat (seperti: Bapak Sulthon Amin yang juga sangat dikenal sebagai pengurus tinggi Muhammadiyah). Selain itu untuk mengisi content informasi zakat dalam majalah dan media sosial serta melayani tanya jawab masyarakat tentang zakat adalah Bapak Imanah, S.Ag. (yang menurut Aditio dipilih karena kecakapannya dalam fikih di Muhammadiyah sekaligus pengalamannya sebagai salah satu ketua MUI Surabaya dari ormas Muhammadiyah). 
Terkait penyadaran berzakat melalui media sosial dan majalah pada dasarnya hampir semua pengurus LAZIS Muhhamadiyah Surabaya boleh berperan menjadi dai sebab banyak pula artikel-artikel informasi yang dipaparkan di majalah dan media sosial merupakan hasil tulisan pengurus LAZIS Muhammadiyah Surabaya yang telah memenuhi syarat untuk ditampilkan. Sosialisasi ke masyarakat dan PCM Muhammadiyah secara langsung banyak dilakukan oleh bapak A. Suja'i sebagai dai yang menyampaikan informasi ke masyarakat, serta dibantu oleh pengurus LAZIS Muhammadiyah yang selainnya untuk penyelenggaraan kesuksesan acaranya.

Untuk penyadaran berzakat melalui kerjasama dengan lembaga-lembaga dilakukan oleh Bapak Sunarko dan A. Suja'i. Bapak Sunarko dan A. Suja'i dipilih sebagai dai dalam penyadaran berzakat melalui kerjasama lembaga karena mereka memiliki kemampuan ceramah yang baik dan statusnya di LAZIS Muhammadiyah Surabaya sebagaoi ketua dan wakil ketua LAZIS Muhammadiyah Surabaya. Sedangkan, kegiatan penyadaran melalui event pengajian dilakukan oleh dai yang berasal pengurus LAZIS Muhammadiyah Surabaya yang tergolong sebagai anggota Korp Mubalig Muhammadiyah.

\section{Mengoperasionalisasi Strategi Penyadaran Berzakat dan Penumbuhan Kepercayaan pada masyarakat}

Dalam rangka menyukseskan kegiatan penyadaran berzakat, LAZIS Muhammadiyah Surabaya juga merencanakan operasionalisasi/teknis strategi penyadaran berzakat, meliputi: a) Pengumpulan dan pemilihan materi penyadaran berzakat

Pada tahap operasionalisasi strategi penyadaran berzakat, setiap bulan diselenggarakan rapat redaksi untuk merumuskan gambaran tema maupun teknis penggalian informasi yang dibutuhkan untuk penyadaran berzakat dan penumbuhan kepercayaan terhadap LAZIS Muhammadiyah Surabaya. Selain melakukan rapat redaksi, tahap selanjutnya yang dilakukan oleh LAZIS Muhammadiyah Surabaya adalah inventarisir content atau bahan penyadaran berzakat. Sumber pesan yang ditampilkan di media sosial dan majalah dikumpulkan dari liputan kegiatan LAZIS Muhammadiyah Surabaya ataupun daerah-daerah lain di Indonesia, wawancara profil muzaki dan mustahik LAZIS Muhammadiyah Surabaya, informasi yang berasal dari ulama Muhammadiyah terkait zakat, infak dan Sedekah dan lain sebagainya. Yang melakukan liputan bisa jadi Aditio (selaku kordinator majalah dan media sosial) maupun pengurus yang lainnya.

Selain ada proses inventarisir konten untuk penyadaran berzakat dan penumbuhan kepercayaan, juga dilakukan proses seleksi bahan sebelum disampaikan atau ditampilkan dalam berbagai media penyadaran berzakat. Dari bahan-bahan yang telah dikumpulkan, tidak semuanya layak ditampilkan di media sosial. Bahanbahan yang telah dikumpulkan Aditio dari teman-teman pengurus

LAZIS Muhammadiyah Surabaya lainnya ataupun informasi lainnya diseleksi dulu baik secara redaksi maupun tema.

"Yah kadang teman-teman ada yang ngasih berita itu, juga ada kegiatan yang tidak penting-penting lah, yah ndak kita 
masukan, ndak ada hubunganya dengan LAZIS Muhammadiyah. yah, jadi saya edit dulu redaksinya. Ada proses seleksi bahan dari yang sudah dikirim oleh teman teman, kadang ada itu tulisan yang saya permak sampai $90 \%$ tulisan itu ada, bahasane gak karuan eh. Akhire bingung maksude opo iki, susun ulang akhire.benerbener mermak. ${ }^{59}$

"Semua bahan harus diseleksi, karena brandingnya harus satu, wajah perwajahan, layout harus satu. Soalnya segala hal yang menyangkut konten yang sifatnya mendasar itu dari pusat (seperti branding, layout). Yang sifatnya materi lokal ya lokal. Kadang-kadang kayak apa tanya jawab dari donatur itu yang jawab LAZIS Muhammadiyah lokal, kan gak harus orang sini nunggu sana, kan lama, jadi lokal kita yang bahas. Sedangkan, dari LAZIS Muhammadiyah pusat ada aturan, pedoman, juklak, juklis, program, program pun harus sama walaupun bahasanya di daerah-daerah beda. Kalau di pusat kan cenderung pakai bahasa Inggris kan, jadi kita terjemahkan ke bahasa kita. Misalnya program save our school, lah orang sini kan ndak tau, jadi Save Our School kan akhirnya diganti beasiswa pendidikan begitu saja. ${ }^{\prime 60}$

"Aturan, pedoman, juklak, juklis, program, program penyadaran berzakat pun harus sejalan dengan LAZIS Muhammadiyah Pusat walaupun bahasanya di daerahdaerah beda. Kalau di pusat kan cenderung pakai bahasa Inggris kan, jadi kita terjemahkan ke bahasa kita. Misalnya program save our school, lah orang sini kan ndak tau, jadi Save Our School kan akhirnya diganti beasiswa pendidikan begitu saja". ${ }^{61}$

Setelah semua bahan terkumpul dan terseleksi baru informasi disampaikan dalam berbagai media. Misalnya dalam majalah dan media sosial, informasi ditampilkan dalam berbagai bentuk, antara lain: materi ceramah, artikel, video, grafik, gambar, karikatur, dan bagan atau tabel.

\footnotetext{
59 Ibid.

60 Ibid.

61 Ibid.
}

Selain itu, khusus untuk media sosial ada fitur atau layanan yang senantiasa diupdate secara berkala. Layanan penyadaran berzakat tersebut seperti: fitur (alat) simulasi penghitung zakat dan tanya jawab zakat (baik melalui media sosial atau surat pembaca di Majalah LAZIS Muhammadiyah Surabaya.

b) Menetapkan intensitas kegiatan penyadaran berzakat

LAZIS Muhammadiyah memiliki standart intensitas penyadaran berzakat untuk masing-masing medianya. Untuk sosialisasi ke PCM-PCM Muhammadiyah Surabaya dilakukan dua kali tiap bulannya. Sedangkan untuk event biasanya dilakukan satu bulan sekali ketika pengajian ataupun dapat ditambah juga jika ada momentum khusus seperti bulan Ramadhan. Untuk majalah dan upload informasi zakat di whatsapp, facebook dan blog satu kali setiap bulannya. Selain itu ada kegiatan kontrol tanggapan masyarakat di media sosial, upload informasi di media sosial tentang kegiatan-kegiatan aktual yang sedang dilaksanakan LAZIS Muhammadiyah Surabaya, meng-update tanya jawab zakat dari masyarakat, input link berita (fitur) dari website LAZIS Muhammadiyah Pusat ke media sosial yang lainnya dan upload tagline-tagline pengingat zakat. $\mathrm{Hal}$ tersebut dilakukan minimal dua hari sekali.

c) Merumuskan struktur penanggung jawab kegiatan penyadaran berzakat

Untuk memperlancar usaha penyadaran berzakat, maka dibentuk struktur untuk pengelolaan kegiatan penyadaran berzakat. Berdasarkan hasil wawancara dengan bapak Sunarko (Ketua LAZIS Muhammadiyah Surabaya), struktur formal (tertulis) yang dibentuk untuk penyadaran 
berzakat adalah struktur yang spesifik menangani media sosial dan majalah. Struktur redaksi majalah LAZIS Muhammadiyah Surabaya, yang sekaligus redaksi media sosial adalah sebagai berikut: 62

Tabel 3 - Struktur Redaksi Majalah LAZIS Muhammadiyah Surabaya

\begin{tabular}{|c|c|}
\hline Jabatan & Nama \\
\hline Penasehat & $\begin{array}{l}\text { Drs. Abdul Wahid } \\
\text { Syukur dan Drs. Sari } \\
\text { Wahyudi }\end{array}$ \\
\hline $\begin{array}{l}\text { Pimpinan Umum dan } \\
\text { Penanggung Jawab }\end{array}$ & Sunarko, S.Ag. \\
\hline Pimpinan Redaksi & Aditio Yudono \\
\hline Sekretaris Redaksi & M. Khoirul Anam \\
\hline Dewan Redaksi & $\begin{array}{l}\text { Imanah, } \\
\text { Syamsun Aly, M.A., } \\
\text { Najib Sulhan, M.A., } \\
\text { Abdul Hakim, M.Pd.I., } \\
\text { Sudarusman, S.T. }\end{array}$ \\
\hline Liputan & $\begin{array}{l}\text { Syaifuddin Zuhri, M. } \\
\text { Alfian Hidayatullah, } \\
\text { Saiful Azzam. }\end{array}$ \\
\hline Litbang & M. Nur Qomaruddin \\
\hline Marketing dan Iklan & May Pandu Winoto \\
\hline Distribusi & Tasmo Dicky Sulaiman \\
\hline
\end{tabular}

Majalah dan media sosial dipimpin oleh Aditio Yadono. Bapak Aditio Yudono ini yang memiliki berbagai ide, baik dalam mengembangkan desain tampilan majalah dan media sosial maupun aspek isi yang disajikan di majalah ataupun media sosial LAZIS Muhammadiyah Surabaya. ${ }^{63}$ Ada beberapa kualifikasi yang kemudian menjadi pertimbangan Ketua LAZIS Muhammadiyah Surabaya memilih Aditio sebagai kordinator media sosial antara lain: kemampuan membuat tulisan (artikel), kreativitas dalam membuat gambar, ideide, tagline, serta dirinya telah aktif mengikuti kegiatan ormas Muhammadiyah

62 LAZIS Muhammadiyah Kota Surabaya, Majalah Donatur LAZIS Muhammadiyah, Edisi 101 Tahun IX, Sya'ban 1437, Mei 2016, 3.

63 Ibid. sejak mahasiswa dan kemudian tertarik untuk membantu LAZIS Muhammadiyah Surabaya ketika ada pembentukan LAZIS Muhammadiyah Surabaya ditingkat cabang. Selain itu, Aditio memiliki kemampuan menjadi admin media sosial yang artinya memiliki kemampuan mengoperasionalkan media sosial dengan baik, seperti membuat blog ataupun mengoperasionalkan media sosial lainnya. Berdasarkan wawancara dengan Mas Aditio, didapatkan informasi bahwa Aditio memiliki kemampuan menulis, salah satunya di media sosial karena pernah ikut pelatihan jurnalistik yang diadakan Radar dan bekerjasama dengan Al-Falah. Struktur lainnya dibentuk secara informal (tidak tertulis) melalui rapat, yaitu penangung jawab sosialisasi kemasyarakat dipimpin oleh Bapak A. Sudja'i. Penyadaran berzakat melalui kerjasama lembaga dan event zakat yang dipimpin oleh Bapak Sunarko.

\section{Analisis Perencanaan Penyadaran Berzakat LAZIS Muhammadiyah Surabaya}

Perencanaan penyadaran berzakat LAZIS Muhammadiyah Surabaya dapat pula disebut sebagai bentuk perencanaan dakwah melalui berbagai media, yang diorientasikan untuk memberikan kesadaran masyarakat muslim kelas menengah. Tujuan perencanaan dakwah ini adalah agar masyarakat terdorong menunaikan kewajiban zakatnya sebagai salah satu rukun iman.

Dalam menyusun perencanaan penyadaran zakat, LAZIS Muhammadiyah melakukan berbagai langkah - langkah sebagaimana dalam teori perencanaan dakwah yaitu: (1) penetapan tujuan penyadaran berzakat 
secara jelas (meliputi efek dakwah yang diharapkan dan sasaran dakwah); (2) analisis situasi (terkait kondisi karakteristik audiens sasaran, media-media yang berpotensi digunakan serta kondisi SDM (kualitas dan kuantitas) yang berpotensi melakukan penyadaran berzakat; (3) merumuskan strategi (cara) dakwah yang sesuai dengan kondisi meliputi: a) penetapan pesan dan memilih media penyadaran berzakat yang sesuai dengan kondisi organisasi dan audiens sasaran LAZIS Muhammadiyah Surabaya, b) pemilihan media dan metode dakwah yang akan digunakan, c) menetapkan dai yang sesuai dalam menyampaikan pesan penyadaran berzakat melalui berbagai media.

Pengurus LAZIS Muhammadiyah Surabaya bukan hanya merumuskan perencanaan strategi dakwah (cara dakwah secara umum), namun LAZIS Muhammadiyah juga merencanakan operasionalisasi strategi seperti dalam hal: a) menetapkan teknis cara untuk dapat menampilkan materi dakwah yang baik (mulai inventarisir bahan, seleksi sampai memutuskan bahan yang akan ditampilkan); b) menetapkan teknis intensitas kegiatan penyadaran berzakat di masing-masing media penyadaran; c) menentukan struktur penanggung jawab pelaksanaan kegiatan penyadaran berzakat.

Perencanaan penyadaran berzakat yang dilaksanakan oleh LAZIS Muhammadiyah Surabaya tidak dapat dilepaskan dari proses analisis situasi yang dilakukan pengurus LAZIS Muhammadiyah Surabaya terhadap karakteristik audiens sasaran (mad'u) penyadaran berzakat yaitu anggota Ormas Muhammadiyah. Sebagian besar warga Muhammadiyah tergolong sebagai masyarakat muslim kelas menengah, yang dipahami pengurus memiliki potensi zakat yang besar dan peluang karakteristik yang unik.

Pengaruh pemahaman pengurus terhadap karakteristik kelas menengah dalam perencanaan yang disusun LAZIS Muhammadiyah Surabaya, Misalnya: dalam penggunaan media dakwah, LAZIS Muhammadiyah Surabaya memilih media sosial sebagai media penyadaran berzakat karena karakter masyarakat muslim kelas menengah cenderung social connection (sadar teknologi informasi). Melalui grupgrup media sosial, pengurus melakukan kegiatan penyadaran yang bersifat interaktif sehingga sangat sesuai dengan karakter kelas menengah. Melalui media sosial, LAZIS Muhammadiyah menjaring tanggapan, tanya jawab, kritik maupun saran-saran dari calon donatur dan donatur. LAZIS Muhammadiyah juga secara aktif melakukan pemantauan dan merespon tiap pertanyaan dari donatur. LAZIS Muhammadiyah Surabaya bahkan memberikan ruang tersendiri di media sosial untuk membuka dialog interaktif dengan donatur dengan dipandu oleh ulama yang kompeten di bidang zakat (salah satu ketua MUI Surabaya dari ormas Muhammadiyah yaitu bapak Imanan, S.Ag). Hal tersebut dipandang pengurus dapat meningkatkan kesadaran masyarakat kelas menengah untuk berzakat dengan ketentuan yang benar.

Selain itu, anggota Muhamammadiyah sebagai audiens sasaran penyadaran berzakat juga memiliki karakter sebagaimana masyarakat muslim kelas menengah secara umum yaitu: cenderung 
terdidik dan rasional. Oleh karena itu, dalam aspek pesan-pesan yang diangkat tidak hanya menekankan pada dalil-dalil Alquran dan hadis, tetapi juga menekankan pada kemanfaatan zakat serta bukti-bukti konkret penyaluran zakatnya yang dapat mengangkat derajat baik pemberi maupun penerima zakatnya. Meskipun demikian, bukan berarti pesan-pesan penyadaran berzakat yang dibawakan LAZIS Muhammadiyah Surabaya terlepas dari dalil-dalil Alquran dan hadis. Karakter masyarakat muslim kelas menengah yang khas ada pada anggota Muhammadiyah antara lain: memiliki kedermawanan yang tinggi, rasional namun juga tidak dapat dilepaskan dari nilai-nilai yang bersifat Islami atau dengan kata lain bersumber dari Alquran dan hadis. Oleh karena itu, aspek informasi tentang kewajiban dan kemanfaatan zakat ditinjau dari Alquran dan hadis masih sangat relevan ditampilkan di berbagai media komunikasi penyadaran berzakat yang digunakan oleh LAZIS Muhammadiyah Surabaya.

Dalam hal metode yang digunakan LAZIS Muhammadiyah Surabaya dalam menyadarkan berzakat pun banyak menggunakan cara-cara yang mampu menunjukan manfaat langsung, seperti: event dan sosialisasi zakat yang diiringi dengan aksi bakti sosial langsung ke masyarakat, media sosial dan majalah yang banyak menekankan pada artikel yang menggambarkan wujud konkret kemanfaatan penyaluran zakat baik bagi muzaki dan mustahik serta memberikan informasi yang terpercaya tentang zakat melalui layanan penghitung zakat dan tanya jawab zakat.
Karakter masyarakat kelas menengah yang dibidik oleh LAZIS Muhammadiyah kebanyakan adalah anggota Muhammadiyah, yang memiliki identifikasi diri tinggi sebagai anggota Muhammadiyah. Pemilihan media dan pesan-pesan penyadaran berzakat, bukan hanya menampilkan manfaat berzakat secara umum namun juga diiringi informasiinformasi yang sangat terikat dengan karakter Organisasi Kemasyarakatan (Ormas) Muhammadiyah serta informasi yang bersumber dari ulama Muhammadiyah sendiri. Hal tersebut, tentunya dapat membangkitkan keterikatan emosi mad'uw untuk mempercayai informasi yang disampaikan karena bersumber dari ormas yang telah terpercaya.

\section{Kesimpulan}

LAZIS Muhammadiyah Surabaya sebagai lembaga nirlaba yang bergerak di bidang edukasi dan perhimpunan zakat secara konsisten melaksanakan kegiatan penyadaran berzakat melalui berbagai media dakwah, yaitu media sosial, sosialisasi zakat, program event zakat, hubungan masyarakat, dan majalah. Strategi penyadaran berzakat LAZIS Muhammadiyah Surabaya lebih menekankan pada pesan informasi yang valid dan menarik tentang nilai kewajiban berzakat ditinjau dari dalil Alquran dan hadis, kemanfaatan zakat baik bagi individu dan masyarakat, serta kemanfaatan zakat secara langsung maupun tidak langsung. Serangkaian strategi penyadaran berzakat yang disusun oleh LAZIS Muhammadiyah Surabaya sangat khas mempertimbangkan karakteristik anggota Muhammadiyah sebagai sasaran komunikasi (mitra dakwah) penyadaran berzakat. Kebanyakan anggota 
Muhammadiyah tergolong kelas menengah muslim perkotaan yang secara umum memiliki karakter sadar akan perkembangan teknologi informasi, berpendidikan (rasional) dan memiliki identifikasi diri yang tinggi sebagai umat muslim sekaligus anggota Muhammadiyah. Selain aspek karakteristik mitra dakwah, dalam penyusunan strategi penyadaran berzakat, LAZIS Muhammadiyah Surabaya juga mempertimbangkan kondisi terkait, seperti karakteristik media yang berpeluang menjadi media penyadaran berzakat dan kerealistisan sumber daya intenal yang dimiliki (khususnya SDM) dalam merealisasikan strategi penyadaran berzakat yang akan dilaksanakan. Dalam menyusun strategi penyadaran berzakat, LAZIS Muhammadiyah Surabaya telah melalui langkah-langkah sistematis perencanaan dakwah mulai penetapan tujuan penyadaran berzakat, perumusan strategi penyadaran berzakat sampai pada perencanaan operasionalisasinya. Meskipun demikian dalam aspek perencanaan operasionalisasinya, LAZIS Muhammadiyah Surabaya belum menyusun secara rinci kebutuhan anggaran diberbagai media yang digunakan, cara penggerakan sumber daya manusia yang akan dilibatkan dalam penyadaran berzakat, dan usaha mengukur (mengontrol) hasil dari kegiatan penyadaran berzakat yang dilakukan.

Studi ini memberikan pemaparan bagaimana potensi masyarakat muslim kelas menengah di Indonesia, karakteristiknya sebagai mitra dakwah yang sangat potensial dalam berzakat. Selain itu, penelitian ini memberikan gambaran bentuk-bentuk penyadaran berzakat yang telah dilakukan secara terencana untuk meningkatkan kesadaran masyarakat muslim kelas menengah dalam berzakat. Harapannya, studi ini dapat menginspirasi berbagai lembaga lainnya untuk mengembangkan strategi penyadaran berzakat yang tidak alamiah guna menjawab masalah rendahnya kesadaran masyarakat Indonesia terhadap berzakat.

Tulisan ini masih berfokus pada deskripsi perencanaan strategi penyadaran berzakat yang dilakukan oleh LAZIS Muhammadiyah Surabaya. Namun, belum mengkaji lebih dalam terkait dengan bagaimana respon/hasil usaha penyadaran berzakat pada masyarakat muslim kelas menengah. Sehingga, untuk penelitian berikutnya akan lebih baik jika dilakukan penenlitian terkait respon (hasil) kualitas kesadaran berzakat masyarakat muslim kelas menengah untuk mengetahui efektifitas strategi penyadaran berzakat yang telah dijalankan.

Dalam perencanaan operasional dakwah yang dirumuskan oleh LAZIS Muhammadiyah Surabaya belum banyak merencanakan pada aspek teknis pengelolaan sumber daya manusia dan dana, serta belum merencanakan langkahlangkah pengukuran hasil kegiatan penyadaran berzakat yang jelas. Untuk meningkatkan efektifitas perencanaan kegiatan penyadaran berzakat dibutuhkan perbaikan dalam beberapa aspek perencanaan tersebut.

\section{Bibliografi}

Agustin, Ayu. "Konstruksi dan Representasi Gaya Hidup Muslim Perkotaan : Studi Kasus Hijabers Community di Jakarta," Skripsi : Universitas Indonesia, Jakarta, 2012. 
Arsanti, Budi. "Pengelolaan Zakat Pada LAZIS Mumahhamadiyah Kabupaten Gunung Kidul," Skripsi, Universitas Islam Negeri Kalijaga, Yogyakarta, 2007.

Azis, Moh Ali. Ilmu Dakwah (Edisi Revisi). Jakarta : Prenadamedia Group. 2016.

Basit, Abdul. Filsafat Dakwah. Jakarta: PT Raja Grafindo Persada. 2013.

Faizah dkk. Psikologi Dakwah. Jakarta : Kencana Prenada Media Group. 2009.

Handoko, Hani, Manajemen Edisi 2. Yogyakarta : BPFE-Yogyakarta. 1994.

Hilyanti, Dewi Laela. “: Aplikasi Manajemen Distribusi Zakat Untuk Usaha Produktif (Studi Kasus Pada LAZIS Muhammadiyah Ranting Tanjung, Kecamatan Purwokerto Selatan, Kabupaten Banyumas)," Skripsi, Universitas Islam Negeri Malang, Malang, 2007.

Huda, Nurul dkk, Prioritas Solusi Permasalahan Pengelolaan Zakat Dengan Metode AHP (Studi Di Banten dan Kalimantan Selatan). Jurnal Al-Iqtishad: Vol. VI No. 2, Juli. 2014.

Krisyantono, Rachmat.Teknik Praktis Riset Komunikasi : Disertai Contoh Praktis Riset Media, Public Relation, Advertising, Komunikasi Organisasi, Komunikasi Pemasaran. Jakarta : Kencana, 2010.

Koontz, Harold dkk. Manajemen Jilid 1 (Edisi kedelapan). Jakarta: Erlangga. 1994.

LAZIS Muhammadiyah Kota Surabaya. Majalah Donatur LAZIS Muhammadiyah. Edisi 101 Tahun IX, Sya'ban 1437. 2016.

Nawawi, Hadri dan M. Matini Nawawi. Instrumen Penelitian Bidang Sosial. Yogyakata: Gajah Mada University Press. 1992.

Mayasari, Nuki. "Rechaging Faith : The Practice of Mutltiple Umrah Trips Among Middle Class in Yogyakarta," Thesis, Universitas Gajah Mada, Yogyakarta, 2014.

M. Raihan Febriansyah, Arief Budiman Ch., Yazid R. Passandre, M. Amir Nashiruddin, Widiyastuti, Imron Nasri. Muhammadiyah 100 Tahun Menyinari Negeri. Yogyakarta : Majelis Pustaka dan Informasi Pimpinan Pusat Muhammadiyah, 2013

M. Munir. Manajemen Dakwah edisi Pertama. Jakarta : Kencana Prenada Media Group. 2009.

Rahayu, "Faktor-Faktor Determinan Motivasi Muzaki Membayar Zakat Ke Lembaga Zakat. Tesis," UIN Sunan Kalijaga, Yogyakarta, 2015.

Robbins, Stephen dkk. Manajemen edisi kedelapan Jilid 1. Indeks. 2009.

Suhandang, Kustadi. Ilmu Dakwah Perspektif Komunikasi. Bandung : \{PT. Remaja Rosdakarya. 2013.

Undang - Undang Republik Indonesia Nomor 23, Tahun 2011, Pasal 17.

Yandianto. Kamus Besar Bahasa Indonesia. Bandung : Percetakan Bandung, 1997.

Yuswohdy, Marketing To The Middle Class Muslim : Pahami Perilakunya, Petakan Strateginya. Jakarta : PT. Gramedia Pustaka Utama. 2014.

Republika, "LAZIS Muhammadiyah filantropi tulang punggung gerakan islam," Republika.co.id, http://khazanah.republika.co.id/berita/dunia-islam/wakaf/15/08/07/nspv8r313-LAZIS Muhammadiyah-filantropi-tulang-punggung-gerakan-islam

Suryanto, "Ketum Baznas: potensi zakat Indonesia Rp200 triliun", dalam http://www.antaranews.com/berita/509484/ketum-baznas-potensi-zakat-indonesiarp200-triliun. (1 Maret 2016), pukul : 17.00.

Tim Redaksi LAZIS NU, Training Manajemen Zakat LAZISNU : Revitalisasi Peran LAZ dalam Pengentasan Kemiskinan, dalam http://www.LAZISnu.or.id/berita/print/100/100 
Wahanani Mawasti 